Article

\title{
Application of DPSIR and Tobit Models in Assessing Freshwater Ecosystems: The Case of Lake Malombe, Malawi
}

\author{
Ishmael Bobby Mphangwe Kosamu ${ }^{1}\left(\mathbb{D}\right.$, Rodgers Makwinja ${ }^{2,3}{ }^{(0}$, Chikumbusko Chiziwa Kaonga ${ }^{1, *}$, \\ Seyoum Mengistou ${ }^{2}$, Emmanuel Kaunda ${ }^{4}$, Tena Alamirew ${ }^{5}$ and Friday Njaya ${ }^{6}$
}

1 Department of Physics and Biochemical Science, Malawi University of Business and Applied Sciences, P/Bag 303, Chichiri, Blantyre 3, Malawi; ikosamu@poly.ac.mw

2 African Centre of Excellence for Water Management, Addis Ababa University, Addis Ababa P.O. Box 1176, Ethiopia; makwinjarodgers@gmail.com or makwinja.rodgers@aau.edu.et (R.M.); seyoumeng@gmail.com (S.M.)

3 Department of Fisheries, Senga Bay Fisheries Research Centre, Ministry of Forestry and Natural Resources, Salima P.O. Box 316, Malawi

4 African Centre of Excellence in Aquaculture and Fisheries (AquaFish), Lilongwe University of Agriculture and Natural Resources, Lilongwe P.O. Box 219, Malawi; ekaunda@yahoo.com or ekaunda@luanar.ac.mw

5 Water and Land Resource Centre, Addis Ababa University, Addis Ababa P.O. Box 3880, Ethiopia; tena.a@wlrc-eth.org

6 Department of Fisheries, Fisheries Deptment Headquaters, Ministry of Forestry and Natural Resources, Capitol Hill, Lilongwe P.O. Box 593, Malawi; fnjaya@gmail.com

* Correspondence: ckaonga@poly.ac.mw or ckaonga07@gmail.com; Tel.: +265-888855399

\section{check for}

updates

Citation: Kosamu, I.B.M.; Makwinja,

R.; Kaonga, C.C.; Mengistou, S.;

Kaunda, E.; Alamirew, T.; Njaya, F.

Application of DPSIR and Tobit

Models in Assessing Freshwater

Ecosystems: The Case of Lake

Malombe, Malawi. Water 2022, 14,

619. https://doi.org/10.3390/

w14040619

Academic Editors: Kun Shi and

Karl-Erich Lindenschmidt

Received: 14 October 2021

Accepted: 6 January 2022

Published: 17 February 2022

Publisher's Note: MDPI stays neutral with regard to jurisdictional claims in published maps and institutional affiliations.

Copyright: (C) 2022 by the authors. Licensee MDPI, Basel, Switzerland. This article is an open access article distributed under the terms and conditions of the Creative Commons Attribution (CC BY) license (https:// creativecommons.org/licenses/by/ $4.0 /)$.

\begin{abstract}
Inland freshwater shallow lake ecosystem degradation is indistinctly intertwined with human-induced factors and climate variability. Changes in climate and human-induced factors significantly influence the state of lake ecosystems. This study provides evidence of the driver, pressure, state, impact, and response (DPSIR) indicators for freshwater lake ecosystem dynamics, taking Lake Malombe in Malawi as a case study. We used the DPSIR framework and Tobit model to achieve the study's objectives. The study's findings indicate that top-down processes gradually erode Lake Malombe's ecosystem state. The lake resilience is falling away from its natural state due to increasing rates of drivers, pressures, and impacts, indicating the lake ecosystem's deterioration. The study shows that demographic, socio-economic, climatic drivers, pressures, state, and responses significantly $(p<0.05)$ influenced the lake ecosystem's resilience. The study suggests that substantial freshwater ecosystem management under the current scenario requires a long-term, robust, and sustainable management plan. The findings from this study provide a roadmap for short-term and long-term practical policy-focused responses, particularly in implementing a freshwater ecosystem restoration programs in Malawi and Africa more broadly.
\end{abstract}

Keywords: DPSIR models; ecosystem state; Lake Malombe; tobit model

\section{Introduction}

Global inland freshwater shallow lakes are under severe stress [1,2]. Duggan et al. [3] identified ecological stressors such as pollution, climate change, over-exploitation, hydrological modification, habitat destruction, and invasion of alien species as the leading causes of freshwater ecosystem degradation. World crises such as poverty, rapid population growth, economic expansion, and climate change are also identified as the most significant emerging threats $[4,5]$. These identified threats are escalating such that the current scale of biodiversity loss in freshwater lakes is rapid and is considered an invisible tragedy while attracting little public, political, or scientific interest [1]. In Africa, climate change, pollution, eutrophication, and invasion of alien species are increasingly threatening the sustainability of inland freshwater shallow lakes [6-10]-impeding efforts to achieve United Nations Sustainable Development Goals (SDGs) —in particular SDG 14 (life underwater), SDG 15 (life 
on land), SDG 13 (climate action), SDG 1 (no poverty), SDG 6 (clean water and sanitation), SDG 2 (zero hunger), SDG 3 (good health and well-being), SDG 12 (responsible production and consumption), and Aichi Biodiversity Targets [11].

Estimates show that about 13 million hectares of global forest lands have been converted to cropland [12]. This conversion has significantly contributed to habitat degradation, eutrophication, pollution, food web alteration, and physical degradation, particularly in inland freshwater shallow lakes [13]. The Living Planet Report revealed that the global freshwater species population has declined by $83 \%$ since the 1970 s, outpacing marine and terrestrial ecosystems. About $32 \%$ of the world's amphibian species are now threatened with extinction, a much higher proportion than threatened birds (12\%) or mammals (23\%), amouting to a total of 168 species [1,3]. About $40 \%$ of river systems globally have already been polluted, with the statistics showing an increasing trend [14]. Eutrophication, pesticides, and alteration of the biological communities continue to threaten ecosystem services' (ESs) functioning [15]. The United Nations Environmental Protection report indicates that about $30-40 \%$ of the lakes and reservoirs in the world have been affected by eutrophication [16]. Davidson \& Finlayson [17] reported that 54-57\% of natural wetlands had been lost, though this figure could be as high as $87 \%$. A tremendous increase in freshwater demand, coupled with rapid population growth, has led to freshwater ecosystem crises [18]. The estimates show that about 3.6 billion people are currently facing water crises, and the projections show an increasing trend to around 5.7 billion by 2050 [19].

Although ecosystem dynamics in most African inland freshwater shallow lakes are not well documented due to a lack of data, it is very apparent that climate change and human activities have negatively affected these lakes [20]. Inland freshwater shallow lakes have been experiencing severe water level drops due to decreased precipitation and above average water temperatures [21-23]. For example, it has been reported that Lake Victoria dried up about 6000 years ago [20]. Once the most significant freshwater lake in Africa, Lake Chad has shrunk dramatically in the last 40 years due to climate variability [24]. In Kenya, Lake Naivasha, an official Ramsar Site (30,000 ha), turned into a shallow mud pool during the 2009 drought [5]. Lake Chilwa has undergone twelve recession periods between 1900 and 2012, resulting in the loss of aquatic biodiversity [25]. The ecosystem of pan-shaped Lake Chiuta in Malawi has shown a high amplification of negative consequences produced by climatic-forcing mechanisms that have impacted Lake Malombe [26]. The water levels and chemical compositions of Lake Kyoga, Lake Tana, Lake Victora, Lake Baringo, Lake Kariba, and Lake Nakuru have changed [27]. The phytoplankton production in Lake Victoria has doubled, and algal biomass has increased fourfold due to increased nutrient enrichment from human activities and industrial and domestic waste [28]. Lake Barigo's depth had decreased from $8.9 \mathrm{~m}$ to less than $1.9 \mathrm{~m}$ by 2003 due to increased human and livestock populations, coupled with deforestation [20]. Only one river is currently flowing of the seven rivers flowing into Lake Barigo in the 1970s. Alien species such as water hyacinth invaded Lake Naivasha in 1988, Lake Victoria in 1990, and is currently reported in river systems such as the Shire River that connects Lake Malawi to Lake Malombe. Salvinia mollesta invaded Lake Kariba in the 1970s and Lake Naivasha in the 1980s [8]. More than $50 \%$ of the endemic fish fauna in Southern Africa are listed as highly threatened categories of the IUCN [29]. There are still visible signs of water quality deterioration in many African freshwater ecosystems where rapid population growth is not matched by an expansion of ecosystem services [30].

Lake Malombe is one of the biodiversity hotspots in Malawi, accommodating various habitat types of terrestrial and aquatic flora and fauna of conservation interest [31-33]. The lake further supports various socio-economic activities such as fisheries and water supply that sustain the local population's livelihoods [34,35]. Despite its ecological and economic significance, the lake has been overstretched due to human actions, climate variability, and landscape transformation $[13,26]$. Due to unprecedented economic pressures, rampant sedimentation, and water quality degradation [32,36,37], increased human population and climate change have further increased the burden on the lake [38]. Attempts were made to 
understand the socio-ecological systems and develop a sustainable ecosystem management plan for the lake $[39,40]$. However, human exploitation frustrated the effort [41]. This paper aims to use the DPSIR and Tobit models to concurrently identify Lake Malombe management priorities and select appropriate monitoring indicators of the lake. The DPSIR model is a socio-economic framework that links the ecosystems' changes to the social and economic drivers and political responses [42]. It was initially developed by the Organisation for Economic Co-operation and Development (OECD) and adopted by the United Nations and the European Environmental Agency [43]. The framework detects and defines processes and interactions in human-ecological systems [44,45] and is highly linked to the ecosystem-based management approach. The DPSIR framework in this study is linked to the following research questions: "What is happening to the Lake Malombe freshwater ecosystem and why? ("D", " $\mathrm{P}$ ", and " $\mathrm{S}$ "), "What are the consequences for the lake ecosystem and local population? (" $\left.\mathrm{I}^{\prime \prime}\right)$, and "what has been done and how effective is it?" " $R$ ". However, to assess the influence of DPSIR indicators on the lake ecosystem, the following research question was framed: "To what extent do the DPSIR indicators influence the Lake Malombe ecosystem?". Since the DPSIR indicators are fragmented, the tobit model is recommended to explain the influence of these indicators on the lake's ecosystem [46].

\subsection{The Theory Underpinning the DPSIR Model}

The Driver-Pressure-State-Impact-Response (DPSIR) model in Figure 1 is an instrument used to detect and define processes and interactions in human-ecological systems [47].

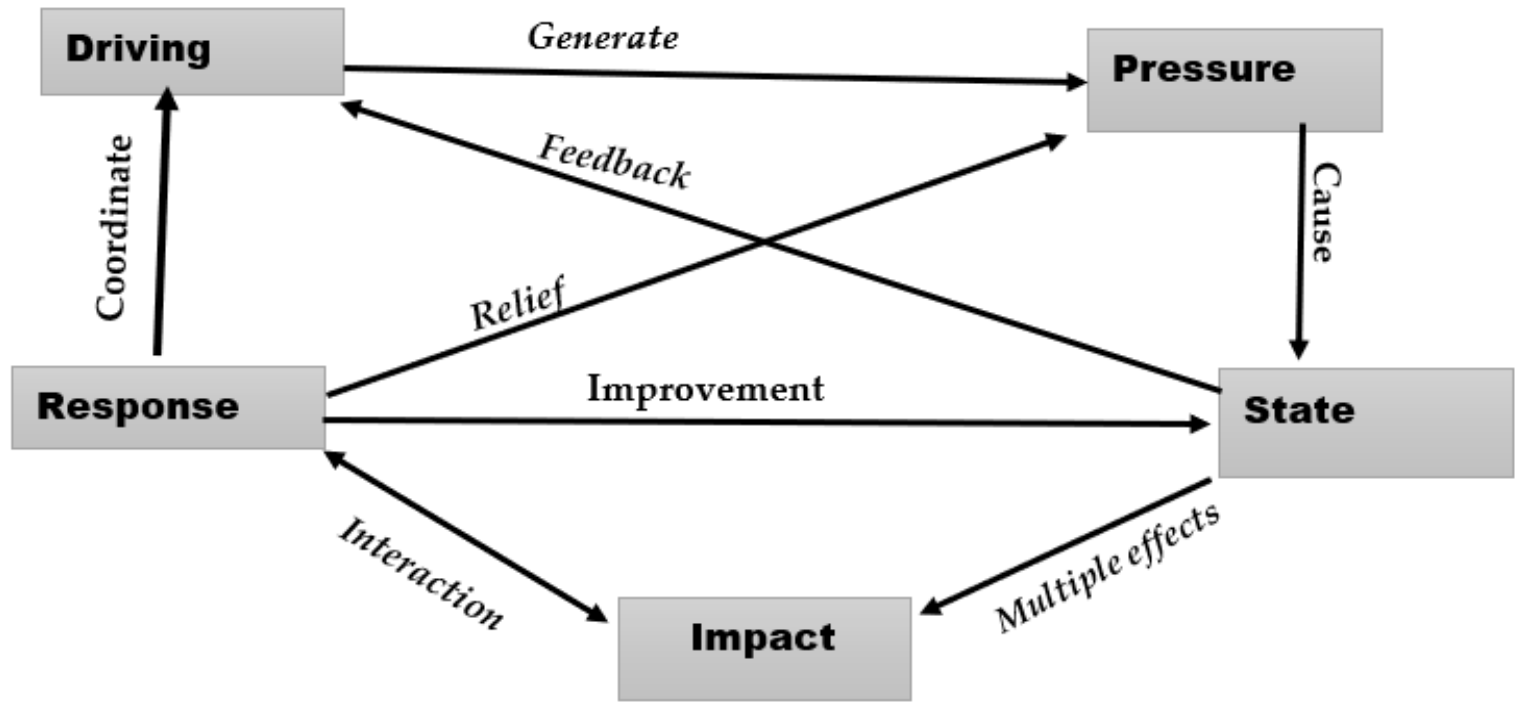

Figure 1. DPSIR conceptual framework.

It was developed in the late 1990s by the Organisation for Economic Co-operation and Development (OECD) and subsequently adopted by the United Nations and the European Environmental Agency [47]. The model provides a precise outlook in understanding the dynamics of the interface between human-natural systems and, in the process, provides a procedure for emptying and evaluating specific elements of this human-nature ecological interface in a manner that is both spatial-temporal on one hand and process-oriented on the other [48]. The DPSIR model uses similar means to other geospatial techniques focused on land-vegetation-dynamic analysis to provide an instructive podium for devaluing the intricacy of such modifications. The approach is recommended by several researchers such as Friend and Rapport [49], Borja et al. [50], Mang et al. [51], Bell [52], Pinto et al. [53], Sarmin et al. [54], Gari et al. [55], and Zare et al. [56], and is derived from PSR (pressurestate-responses)—with (D) being added later to describe underpinning drivers. 


\subsection{The Debate over the DPSIR as a Policy Supporting Tool}

The DPSIR framework is known for its potential and usefulness in research to provide policymakers with a clear and meaningful explanation of cause-effect relationships. According to Gebremedhin et al. [57], the DPSIR model helps summarize and visualize the cause-effect interactions of the lake ecosystem in a simplified way. The Malawi government recommended the DPSIR framework in its Decentralized Environmental Management Guidelines [58]. The model extensively analyzed environmental issues originating from human activities [52]. Malawi's 2010 State of Environmental Outlook Report also adopted the integrated environmental ssessment approach based on the DPSIR model to depict environmental trend dynamics in Malawi. Other researchers have also described the model as helpful in providing the basis for policy-relevant research [59]. Although the DPSIR model has received enormous support, many heated arguments have been going on over recent decades regarding its relevance to ecosystem management, especially at the local level. Niemeijer and De Groot [60] argued that the DPSIR model focuses too much on unidirectional causalities between indicators and does not address the complex interrelationships found in reality. Other studies have noted that the DPSIR model framework does not demonstrate how different drivers and responses can be dealt with locally [61]. The model has further been disputed for failing to consider social concerns [58]. In other words, the DPSIR model ignores certain critical viewpoints and concerns of the affected groups of individuals [43]. It further displays a selective understanding of issues, making other researchers argue that the model could be biased and deemed irrelevant by some actors whose concerns are ignored [43]. Ecologists have always argued that humans protect what they value [62]. A natural ecosystem can only be protected by those who benefit from it. Individuals or groups affected by ecosystem change due to social and ecological changes have the potential to find a sustainable solution to address the impact [61]. This implies that failure to consider the concerns of many individuals could make ecosystem management complex [63]. Therefore, several researchers have suggested various approaches to improve the model to make it more flexible and easy to understand in order to communicate with various stakeholders at multiple levels. Tscherning et al. [43] suggested that incorporating social and economic concerns into the DPSIR model could make the model more effective and relevant. Svarstad et al. [63], on the other hand, suggested that various narratives need to be applied in the DPSIR model to accommodate multiple discourses of stakeholders. Niemeijer and De Groot [60] also suggested that unidirectional causal chain networks need to be replaced with multiple causal chain networks to provide a more reliable basis for selection, identify and specify indicators, and effectively help policymakers and managers to determine the precise starting points of monitoring. It is further noted that the application of the DPSIR model, along with other approaches, may provide baseline data for further research and assist researchers in framing their research objectives based on practical issues.

\section{Materials and Methods}

\subsection{Study Area}

Lake Malombe, in Figure $2\left(14^{\circ} 40^{\prime} 0^{\prime \prime} \mathrm{S}\right.$ and $\left.35^{\circ} 15^{\prime} 0^{\prime \prime} \mathrm{E}\right)$, occupies a narrow north-south tectonic basin at the southern extension of the East African Great Rift Valley complex. It is the second-largest inland freshwater shallow lake in Malawi with a water depth of less than $6 \mathrm{~m}$, length of $30 \mathrm{~km}$, and width of $17 \mathrm{~km}$ [32]. Hydrologically, the inflow and outflow of the Shire River make the most significant contribution to Lake Malombe's water budget, except during the drought period when Lake Malawi's water level is too low to feed into Shire River [64]. 


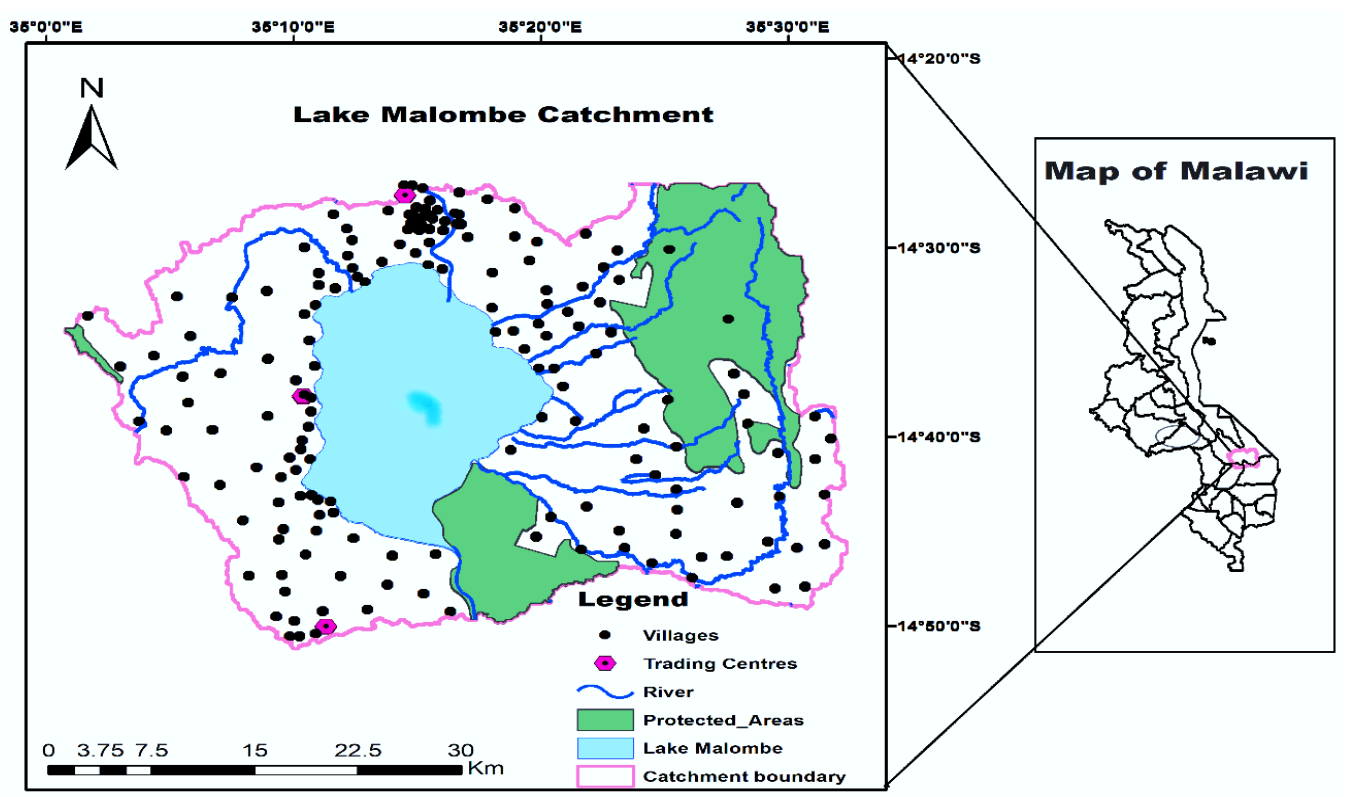

Figure 2. Map of Lake Malombe catchment (Makwinja et al., 2021a).

The rainfall period falls into three categories; early rainfall characterized by heat thunderstorms over the high ground of the escarpment area occur in October and November, the inter-tropical convergence zone (ITCZ) and the eastward encroachment of the moist Congo air mass associated with thunderstorms in December and March, and the southeasterly wind that brings rainfall over high ground in April and May. The temperature ranges from $13{ }^{\circ} \mathrm{C}$ to $35^{\circ} \mathrm{C}$, and average annual rainfall ranges from $600 \mathrm{~mm}$ on the rift valley floor to $1600 \mathrm{~mm}$ in the mountainous areas. Lake Malombe plays an essential role in the local economy and biodiversity protection. Its catchment consists of diverse habitats, including grassland, forest, shallow tidal areas, open waters, swampland, and mangroves that support diverse terrestrial and aquatic flora and fauna. The lake ecosystem supports approximately $90 \%$ of the local population in fishery activities within $10 \mathrm{~km}$ of the lake.

\subsection{Data Collection}

\subsubsection{Grey Literature Search Strategy and Documentation}

The framing of the DPSIR model indicators began with a systematic search of documentation. The DPSIR indicator selection was based on the following criteria: (1) indicator reflects ecosystem changes in state and management; (2) availability, accessibility, and consistency of indicators within the specified period of analysis; (3) independence and ability to eliminate multicollinearity; and (4) representation and superiority of the indicator over other indicators in a similar category. These criteria were achieved by searching available databases and their information within the specified period. Several scientific peer-reviewed article databases, including ScienceDirect, ResearchGate, Google Scholar, Web of Science, SciELO, LibGen, PubMed, Science-Hub, internet archives, Scopus, CrossRef, EcoPapers, BioOne, academic research databases, and others were searched. These databases were chosen based on their ability to highlight various similar peer-reviewed articles. The targeted sources were peer-reviewed journal articles, book sections, and scientific reports written in English.

We used multiple keyword combinations such as "Lake Malombe Pressure-StateResponses," "Lake Malombe Pressure-State-Impact-Responses," "Lake Malombe DriverPressure-State-Impact-Response," "Lake Malombe State change," "Lake Malombe PressureState-Response," "Lake Malombe Pressure-State-Impact Responses," "Lake Malombe Driver-Pressure-State-Effect-Action," "Lake Malombe State-Change," and "Lake Malombe Pressure-Response model". The primary database search involved screening titles and abstracts based on keywords. The open search yielded 600 scientific peer-reviewed arti- 
cles, reports, and policy documents. The articles were further classified into "General" (those that were general and focused on the concept of freshwater ecosystems broadly) and "Specific" (those articles explicitly focusing on the Lake Malombe ecosystem). The articles accessed from peer-reviewed journals were further assessed based on the publisher's ranking ( $\mathrm{A}^{*}$ to $\mathrm{C}$ ) where " $\mathrm{A}$ " indicates highly credible sources and " $\mathrm{C}$ " credible sources, the relevance of the research article to the research theme, publisher identity, and reliability. These research selection criteria resulted in 105 scientific articles. The selected research articles were categorized as national (those conducted in Malawi), local (those specific to Lake Malombe), regional, and global. Data collected from the systematic review were used in qualitative and quantitative analysis.

\subsubsection{Primary Data}

Three traditional authorities (T/As), namely T/A Mponda, T/A Chimwala, and T/A Chowe, were ultimately selected for interviews. These three traditional authorities engage in fishing and farming and represent the two predominant Lake Malombe livelihood groups, inland and shoreline, each with distinct socio-ecological characteristics. Six university graduates coordinated face-to-face interviews held in Yao or Nyanja-native languages. The interviews were audio-recorded with participant consent and transcribed for fundamental content analysis. Semi-structured interviews were conducted with individuals in each community. Local leaders were approached first, then additional participants were engaged through the snowball sampling technique. The semi-structured format ensured that all key questions were addressed while providing ample space for the respondents to freely express their own experiences, opinions, and knowledge of the lake ecosystem DPSIR indicators. The interviews covered household activities, changes in the lake ecosystem service functions, the socio-ecological system, and associated coping mechanisms. Four focus group discussions (FGDs) per traditional authority were organized separately for households whose dominant livelihood was fishing or farming, with 10 to 12 villagers representing different socio-economic and demographic backgrounds. This design made it possible to capture a representative cross-section of residents and avoid bias through overly influential individuals. Each FGD consisted of two parts: in the first part, the participants constructed a timeline of social-ecological development from the 1970s onward, mapping and identifying critical drivers linked to ecosystem changes, pressures, current ecological conditions, livelihood activities, governance structure, and responses and ranking them based on the consensus reached. The second part involved the mental models. The mental model systematically identifies and deliberates critical events and drivers of the lake ecosystem dynamics that threaten its resilience, interaction, causes (pressures), state, consequences (impacts) for ecological and livelihood dynamics, coping mechanisms, and future policy directions. Several transect walks accompanied by villagers were also undertaken to households, local markets, fish landing sites, and farmlands to help us understand the lake ecosystem, landscape, socio-economic activities, and other livelihood practices.

The consultative meetings were conducted with the Mangochi District Environmental Office, the District Agriculture Development Office, the District Forest Office, the District Water Office, the District Disaster Risk Management Office, the District Director of Planning and Development Office, the District Fisheries Office, and the Liwonde National Park Office. Data collected from the consultative meetings helped us to develop the DPSIR framework following the Organisation for Economic Co-operation and Development (OECD) framework. The participatory rapid appraisal (PRA) approach was also used to collect data focusing on drivers, pressures, state change, impact, previous responses, and other related critical issues and was achieved through direct involvement with the local communities in the study area. The PRA encompassed a wide range of field trips, interviews, informal meetings, field observations, and in-depth key informant interviews. Before visiting the study area, a list of broad questions about the Lake Malombe ecosystem functions were framed. The duration of the field study was 30 days. The interviews and meetings were 
recorded and notes were taken after asking for interviewees' consent. The field trips were wrapped up by promising to send the interviewees a feedback report of the findings.

\subsection{Construction of DPSIR Framework and Data Weighting}

Weighting techniques were employed to select the appropriate indicators for the DPSIR framework. Specifically, entropy and analytic hierarchy techniques were used to weight indicators in different DPSIR networks. "Pressure," "state," and "response" were weighted using the hierarchy procedure. The entropy weighting technique was used to select appropriate "driving force" indicators and "impacts." The ecosystem resilience performance was demonstrated using a plot. The index of each DPSIR class was determined, after pre-determined indicator weighting, using the following specific steps [65]:

$$
\begin{gathered}
X_{i j}^{\prime}=\frac{X_{i j}-\min \left(X_{1 j}, X_{2 j}, \ldots, X_{n j}\right)}{\max \left(X_{1 j}, X_{2 j}, \ldots, X_{n j}\right)-\min \left(X_{1 j}, X_{2 j}, \ldots, X_{n j}\right)}+1 \\
i=1,2, \ldots, n ; j=1,2 \ldots, m
\end{gathered}
$$

Equation (1) demonstrates that greater the index, the more reliable it is. Conversely, Equation (2) suggests that indicators with a smaller index are best. Note that $n$ means the number of indicators, $m$ is a valuation indicator, and $x_{i j}$ is an index.

$$
\begin{gathered}
X_{i j}^{\prime}=\frac{\max \left(X_{1 j}, X_{2 j}, \ldots, X_{n j}\right)-X_{i j}}{\max \left(X_{1 j}, X_{2 j}, \ldots, X_{n j}\right)-\min \left(X_{1 j}, X_{2 j}, \ldots, X_{n j}\right)}+1 \\
i=1,2, \ldots, n ; j=1,2 \ldots, m
\end{gathered}
$$

The next step is to calculate the proportion of the $i$-th plan under the $j$-th indicator:

$$
\rho_{i j}=\frac{\left(X_{i j}^{\prime}\right)}{\sum_{i=1}^{n} X_{i j}^{\prime}}+1, \quad j=1,2, \ldots, m
$$

The entropy of the $j$-th indicator is calculated as:

$$
e_{i}=\frac{1}{\ln n_{i-1}} \sum_{i=1}^{n} p_{i j} \ln p_{i j}
$$

The weight indicator is calculated as:

$$
W_{i}=\frac{1-e_{i}}{\sum_{j=1}^{n}\left(1-e_{i}\right)}, j=1,2, \ldots, m
$$

The comprehensive score of each indicator is determined as:

$$
S_{i}=\sum_{j=1}^{m} W_{j} * \rho_{i j}, \quad 1,2, \ldots, n
$$

\subsection{Tobit Model}

James Tobit introduced the Tobit model in 1958. The model assumes that many variables have a lower or upper limit and takes these as limiting values. For example, the decision as to whether the Lake Malombe ecosystem is changing may be characterized as a dichotomous choice between two mutually exclusive alternatives (negative or positive). A breakpoint in the explanatory variables could depict this. In the Tobit model, Y denotes that the change in the lake ecosystem function depends on DPSIR indicators and could be expressed as $x$ vectors meaning explanatory variables. The $Y$ variable is defined in the context of a limited variable that takes on two values; $\mathrm{Y} \sim Y^{*}$ if the results of the 
ecosystem change are positive and $\mathrm{Y} \sim 0$ if the results are negative. It should be noted that the probability $y$ takes only values of 1 or 0 [65] and the thresholds of all members in the sample are distributed among different values of the explanatory variables. This can be demonstrated by a sigmoid curve (Figure 3).

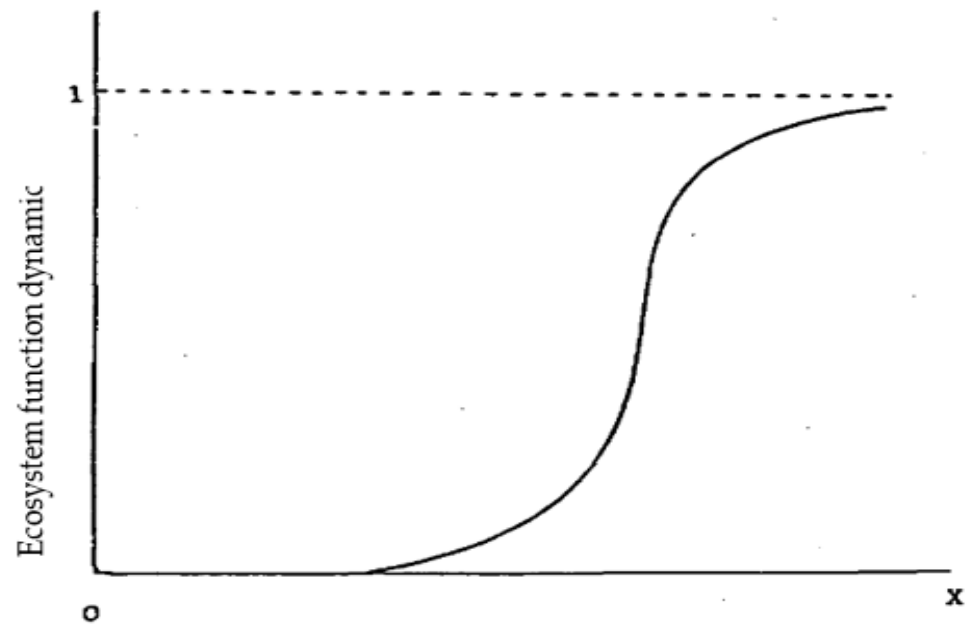

Figure 3. A sigmoid curve of Lake Malombe ecosystem function dynamics.

The explanatory variables (DPSIR indicators) considered in the Tobit model include a demographic driver (Dd), socio-economic drivers (Ds), climatic drivers (Dc), pressures $(\mathrm{P})$, socio-economic states (Ss), environmental states (Se), impacts (I), capacity building and governance responses (RCBG), institutional measure responses (RIM), livelihood intervention responses (RLI), and environmental intervention responses (REI). Having clarified these concepts, we define a Tobit model [66] as follows:

$$
Y^{*}=X^{\prime} \beta+\varepsilon, \text { with } \varepsilon \mid X \sim N\left(0 ; \delta^{2}\right) \text {, with } y=y^{*} \text { if } y^{*}>0 \text {, and } y=0 \text { otherwise }
$$

where $y$ is the observed variable of interest, and $Y^{*}$ is a latent variable. The above equation describes three things. First, the expected effect of $x$ on $Y^{*}$ is monotonic. Second, the residuals follow a normal distribution. Lastly, the dependent variable is left censored.

\subsection{Data Analysis}

Data were analyzed using a critical discourse approach and content analysis. The DPSIR framework guided the identification, structuring, and representation of system elements and their interactions. Field recordings were decoded and notes were scanned to identify, classify and group various stakeholders' ideas and concepts. Metadata from primary sources were exported in STATA version 15 and analyzed using descriptive and inferential statistics.

\section{Results}

This study analyzed the Lake Malombe freshwater ecosystem using the DPSIR model (Figure 4). The primary goal was to provide concise and specific information about the driving forces, socio-economic and environmental pressures, socio-economic and environmental states, impacts resulting from spatial and temporal changes of the lake, and responses. 


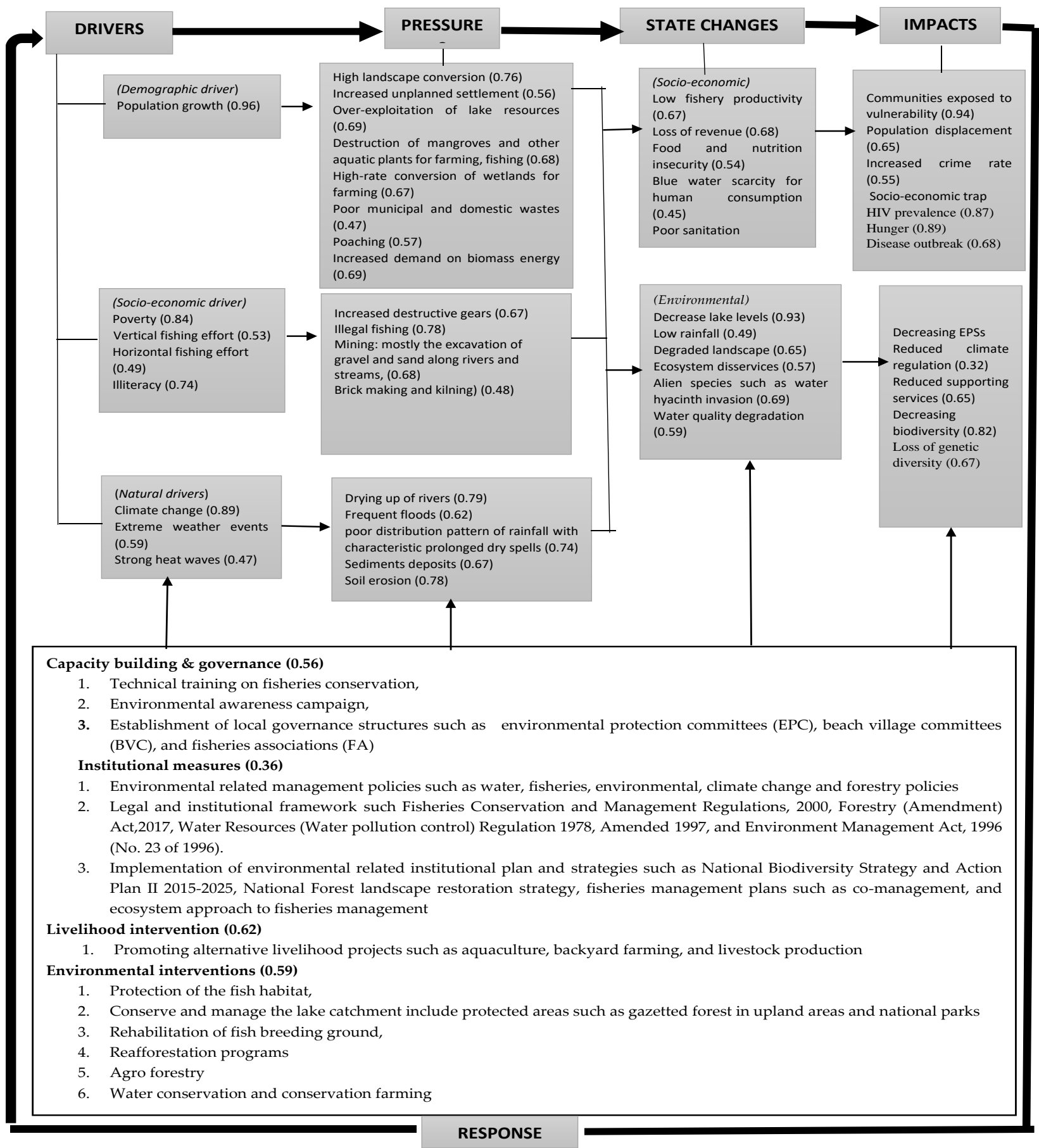

Note: The values represent weight valuation index (rated at the scale of 0 to 1 where 0 means least essential and 1 the most significant).

Figure 4. DPSIR model for Lake Malombe Inland freshwater shallow lake.

\subsection{Drivers and Pressures}

The driving force is the root cause for the spatial and temporal changes of the lake ecosystem state (Figure 4). It can be interpreted as a demographic, socio-economic, or natural factor.

The stakeholders ranked rapid population growth as the highest indicator for the demographic driver (0.96). The pressure associated with this driver includes high landscape conversion, increased unplanned settlement, over-exploitation of lake resources, destruction of mangroves and other aquatic plants for farming, fishing, high-rate conver- 
sion of wetlands into farmlands, buildup of municipal and domestic waste, poaching, and increased demand for biomass energy (Figure 5).
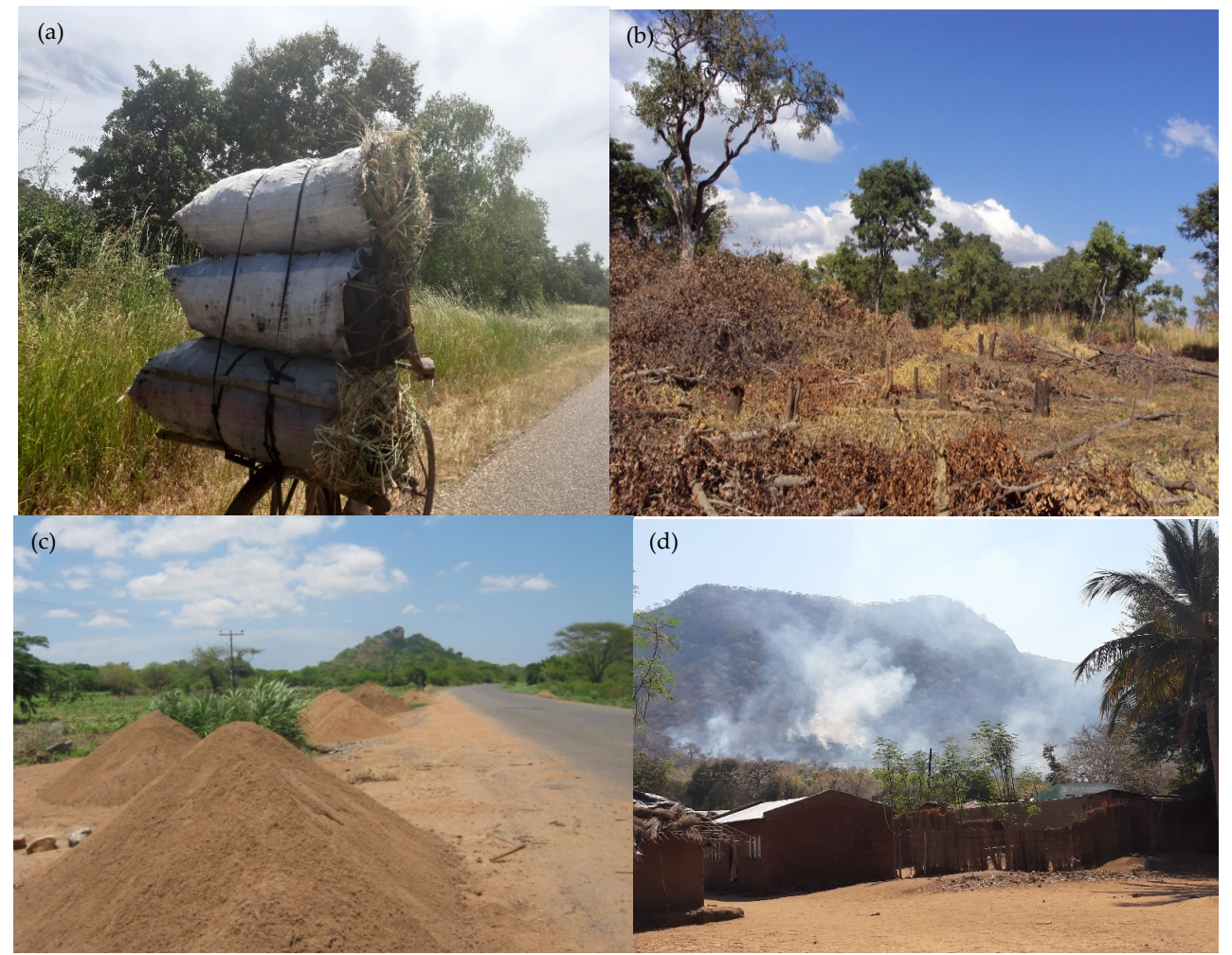

Note: Photo (a) shows a man carrying charcoal to sell at Mangochi town; photo (b) indicates the deforested area; photo (c) shows the sand extracted from the rivers ready for sale; and photo (d) indicates the burning of forest land for farming and charcoal production

Figure 5. Pressure on the Lake Malombe ecosystem.

Poverty was the highest (0.84) socio-economic driver, followed by illiteracy (0.74). Vertical fishing efforts (0.53) and horizontal fishing efforts (0.49) ranked the lowest. The pressures triggered by these socio-economic drivers include illegal fishing (0.78) (ranked the highest), gravel and sand mining along rivers and streams (0.68) (Figure 5), increased destructive gears (0.67), brick making, and kilning (0.48). Climate change was ranked the highest (0.89) natural driver, with extreme weather events $(0.59)$ and strong heat waves (0.47) ranked the lowest. The pressures triggered by these drivers include the drying up of rivers (0.79), frequent floods (0.62), a poor rainfall distribution pattern characterized by prolonged dry spells (0.74), soil erosion (0.78), and sediment deposits (0.67), as expressed by the following anecdote: "During the intense precipitation, debris from the upland areas are washed away into the lake damaging the mangroves and contribute to the lake siltation."an older man at Chimwala Village, Nov 2019. Figure 6 shows comprehensive indices for drivers and pressures exerted on the Lake Malombe ecosystem from 1970 to 2020. 


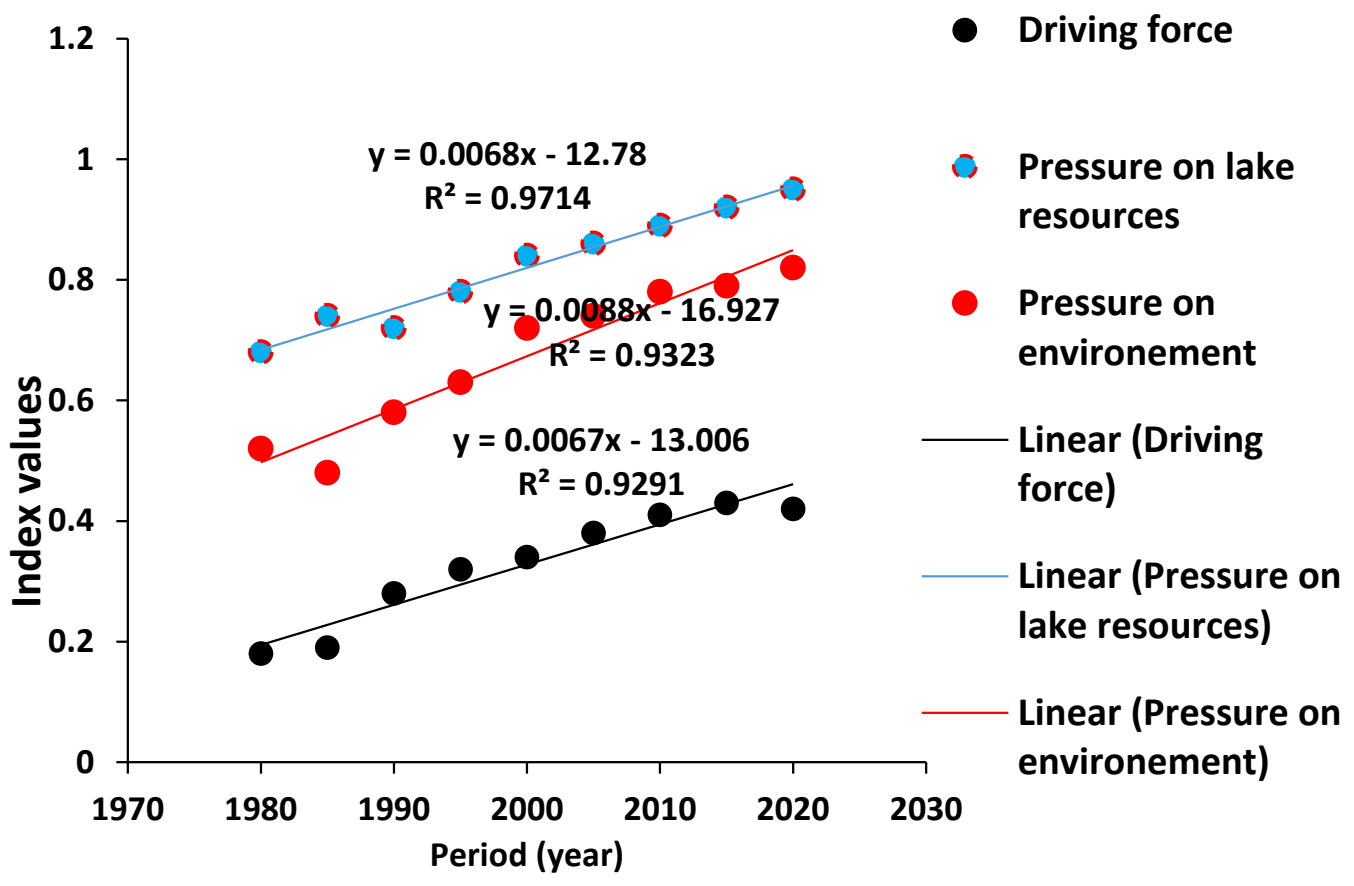

Figure 6. Inter-annual variation of the driver and pressure index.

The inter-annual variation index followed the linear pattern demonstrated by the linear regression coefficients $(\mathrm{R}$ squared $=0.9$ ). The theoretical explanation of the current observation is that these drivers and pressures will continue influencing the spatial and temporal changes of the ecosystem.

\subsection{State and Impacts}

The state index refers to the condition of the lake ecosystem resulting from drivers such as demographics, socio-economic factors, and natural factors and pressures such as environmental factors. The socio-economic states comprised those factors affecting the local population's well-being. The stakeholders mentioned low fishery productivity (0.67), disease outbreak (0.87), loss of revenue (0.68), and food and nutrition insecurity (0.54) as the socio-economic states. The environmental states comprised factors such as decreased lake levels (0.93), water quality degradation (0.59), low rainfall (0.49), degraded landscape (0.65), ecosystem disservices (0.57), and alien species such as water hyacinth invasion (0.69) that affect the lake ecosystem function. Lake ecosystem resilience changes impact the local population and the environment. In this study, the impact index is defined as the socioeconomic and environmental impacts that affect the local population's livelihood, social welfare, and the environment due to the changing state of the lake ecosystem. The impacts in this study were linked to socio-economic factors, which include communities' exposure to vulnerability (0.94), population displacement $(0.65)$, increased crime rate $(0.55)$, socioeconomic traps, HIV prevalence (0.87), hunger (0.89), and disease outbreak (0.68). The environmental state is linked to impacts such as decreasing ecosystem provisioning services (EPSs), reduced climate regulation (0.32), reduced supporting services (0.65), decreasing biodiversity (0.82), and loss of genetic diversity (0.67). Figure 7 shows the comprehensive indices of the states and impacts on the Lake Malombe ecosystem.

The coefficients of linear regression (R squared) for state and impact were above 0.9, suggesting that these dependent variables are the function of the explanatory variable (time) and that the current state and impact will continue to increase with time. 


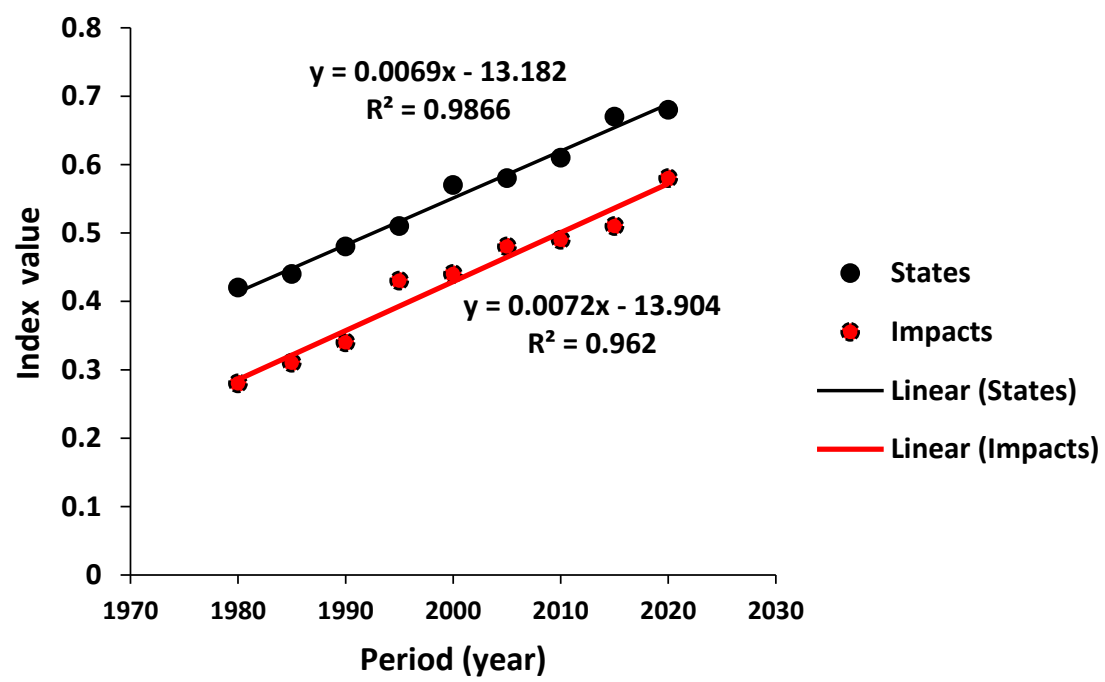

Figure 7. Inter-annual variation of the state and impact index.

\subsection{Responses}

The response index refers to the measures taken to improve the state of the lake. These measures may act towards any DPSIR indicators within the framework to ensure the lake ecosystem's high efficiency and resilience. Apart from direct actions acting on the DPSIR indicators, the responses focusing on behavioral and attitude changes towards changes to the lake ecosystem through participation and involvement are vital. Different stakeholders interviewed mentioned various strategies to acknowledge the existing drivers, pressures, states, and impacts around Lake Malombe. These strategies were classified into capacity building and governance (0.56), institutional measures (0.36), livelihood intervention (0.62), and environmental interventions (0.59). Capacity building focuses on equipping local communities with the skills and knowledge required to manage the lake ecosystem. These include technical training on biodiversity conservation, ecosystem services, and environmental awareness campaigns.

Governance is focused on the establishment of local structures such as environmental protection committees (EPC), beach village committees (BVC), and fishery associations (FA) to champion the management of the lake ecosystem. Institutional measures include government policies, institutional frameworks, and management strategies. Examples of management policies mentioned during the key informant interviews and FGDs include water, fishery, environmental, climate change, and forestry policies. The legal and institutional frameworks include the Fisheries Conservation and Management Regulations of 2000, the Forestry (Amendment) Act of 2017, the Water Resources (Water pollution control) Regulation Act of 1978 (amended 1997), and the Environment Management Act of 1996 (No. 23 of 1996). The management plans and strategies include the National Biodiversity Strategy and Action Plan II (2015-2025), the National Forest Landscape Restoration Strategy, fisheries management plans such as co-management, and the ecosystem approach to fishery management. Livelihood interventions are activities, such as aquaculture, backyard farming, and livestock production, that aim to promote the local population's welfare. Environmental interventions focus on restoring the lake ecosystem. The environmental interventions identified from the interviews include protecting the fish habitat, conserving and managing the lake catchment (including protected areas such as the gazetted forest in upland areas and national parks' rehabilitation of fish breeding grounds), reafforestation programs in agroforestry, water conservation, and conservation farming. Figure 8 shows the comprehensive indices of responses to drivers, pressures, states, and impacts on the Lake Malombe ecosystem over time. 


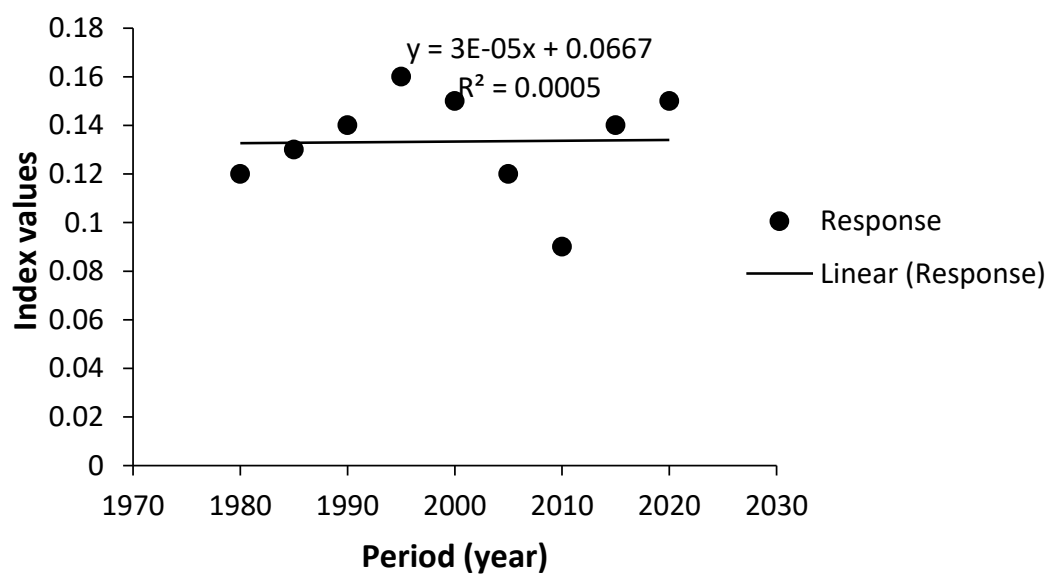

Figure 8. Inter-annual variation of the state and impact index.

The coefficients of linear regression ( $\mathrm{R}$ squared) for the responses being above 0.0005 suggests that the initiatives taken in Lake Malombe to reverse past and current trends are inadequate to address the drivers, pressures, state, and impacts.

\subsection{Lake Malombe Ecosystem Resilience and Influencing Factors}

Lake Malombe's ecosystem state can be depicted as a multidimensional surface where troughs and crests represent the lake ecosystem's stable and unstable state. Figure 9 shows that the lake ecosystem is drawn to troughs, in which resilience is equivalent to the depth of a depression that keeps an ecosystem state at equilibrium with time. At the equilibrium, the lake ecosystem is resilient to drivers, pressures, and impacts that noticeably change the ecosystem state around the trough.

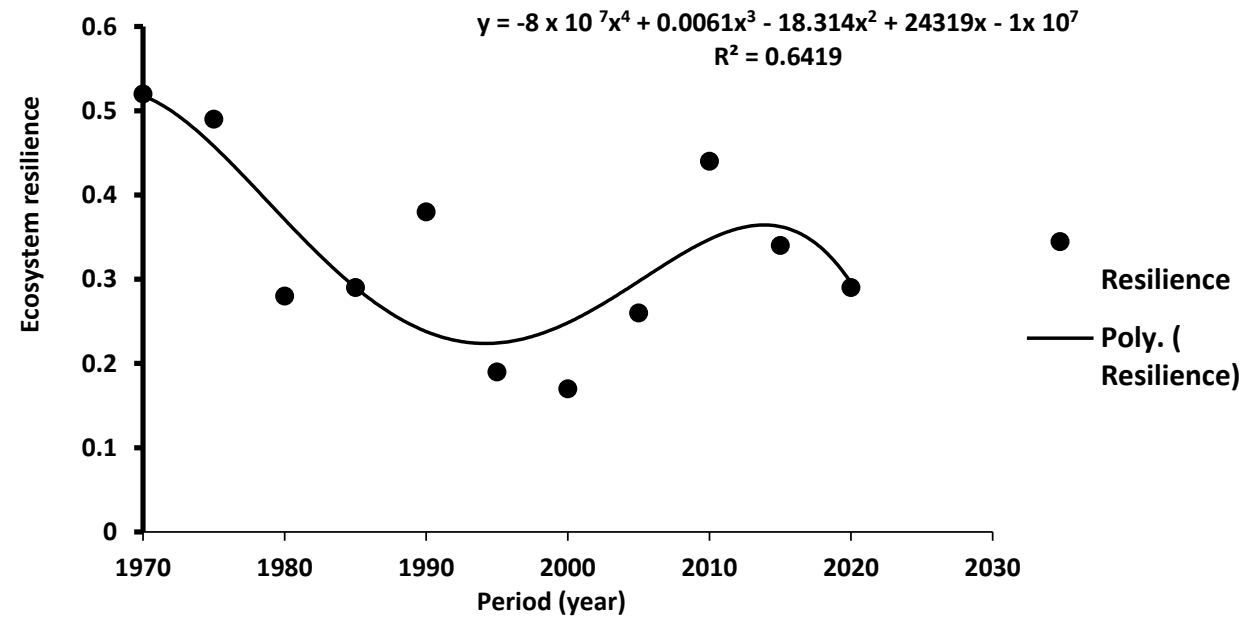

Figure 9. A cup diagram illustrating the Lake Malombe ecosystem's resilience.

A reduction in resilience is illustrated as a shallowing of the depression due to increased demographic, socio-economic, and natural drivers and pressures. Entropy techniques modify the weight of the DPSIR indicators. By calculating the weight of each indicator, key factors that influence the lake ecosystem resilience were identified. The multicollinearity test was conducted before regression analysis to check whether the covariates in the Tobit model were independent of each other. The correlation coefficient matrix in Table 1 showed no multicollinearity in the model, suggesting that the selected variables fit the regression analysis. 
Table 1. Correlation matrix of variables.

\begin{tabular}{|c|c|c|c|c|c|c|c|c|c|c|c|}
\hline & $\mathrm{Dd}$ & Ds & Dc & $\mathrm{P}$ & Ss & Se & I & RCBG & RIM & RLI & REI \\
\hline Dd & 1 & & & & & & & & & & \\
\hline Ds & 0.33 & 1 & & & & & & & & & \\
\hline Dc & 0.12 & 0.06 & 1 & & & & & & & & \\
\hline $\mathrm{P}$ & 0.01 & 0.00 & 0.03 & 1 & & & & & & & \\
\hline Ss & 0.21 & 0.31 & 0.18 & 0.12 & 1 & & & & & & \\
\hline Se & 0.02 & 0.10 & 0.15 & 0.09 & 0.13 & 1 & & & & & \\
\hline I & 0.07 & 0.01 & 0.21 & 0.10 & 0.11 & 0.20 & 1 & & & & \\
\hline RCBG & 0.02 & 0.13 & 0.11 & 0.13 & 0.03 & 0.12 & 0.03 & 1 & & & \\
\hline RIM & 0.02 & 0.12 & 0.02 & 0.03 & 0.02 & 0.09 & 0.02 & 0.07 & 1 & & \\
\hline RLI & 0.04 & 0.06 & 0.04 & 0.00 & 0.02 & 0.04 & 0.00 & 0.08 & 0.24 & 1 & \\
\hline REI & 0.11 & 0.1 & 0.13 & 0.14 & 0.11 & 0.21 & 0.13 & 0.16 & 0.21 & 0.02 & 1 \\
\hline
\end{tabular}

Note: $\mathrm{Dd}=$ demographic drivers, $\mathrm{Ds}=$ socio-economic drivers, $\mathrm{Dc}=$ climatic drivers, $\mathrm{P}=$ pressures Ss = socio-economic state, $\mathrm{Se}=$ environmental state, $\mathrm{I}=$ impact, $\mathrm{RCBG}=$ capacity building and governance responses, $\mathrm{RIM}=$ institutional measure responses, $\mathrm{RLI}=$ livelihood intervention responses, $\mathrm{REI}=$ environmental intervention responses.

The Augmented Dickey-Fuller (ADF) co-integration test in Table 2 shows that $p<0.05$, indicating the existence of a co-integration relationship in the panel data. Demographic, socio-economic, and climatic drivers, pressures, socio-economic state, and environmental state were significant $(p<0.05)$ and negative, suggesting that these indicators negatively influenced the lake ecosystem's resilience.

Table 2. The empirical results of the Tobit model.

\begin{tabular}{|c|c|c|c|c|}
\hline $\begin{array}{c}\text { DPSIR } \\
\text { Indicators }\end{array}$ & Coefficient & Std.Error & z-Statistic & $p$ Value \\
\hline $\mathrm{D}_{\mathrm{d}}$ & -0.060 & 0.010 & -3.201 & 0.003 \\
\hline $\mathrm{D}_{\mathrm{s}}$ & -0.086 & 0.021 & 2.710 & 0.041 \\
\hline $\mathrm{D}_{\mathrm{c}}$ & -0.056 & 0.010 & 6.619 & 0.021 \\
\hline $\mathrm{P}$ & -0.065 & 0.010 & 4.321 & 0.044 \\
\hline Ss & -0.089 & 0.007 & 4.120 & 0.004 \\
\hline Se & -0.002 & 0.002 & 3.231 & 0.003 \\
\hline I & -0.007 & 0.001 & 2.043 & 0.043 \\
\hline $\mathrm{R}_{\mathrm{CBG}}$ & 0.012 & 0.012 & 0.450 & 0.059 \\
\hline $\mathrm{R}_{\mathrm{IM}}$ & 0.094 & 0.001 & 0.013 & 0.048 \\
\hline $\mathrm{R}_{\mathrm{LI}}$ & 0.063 & 0.001 & -4.234 & 0.021 \\
\hline $\mathrm{R}_{\mathrm{EI}}$ & 0.012 & 0.012 & 6.450 & 0.012 \\
\hline
\end{tabular}

Heteroskedasticity and autocorrelation-consistent (HAC) ADF $t$-test $=-88.032, \mathrm{HAC}=0.003$, residue variance $=0.01, p$ value $=0.001$. Note: $\mathrm{Dd}=$ demographic drivers, $\mathrm{Ds}=$ socio-economic drivers, $\mathrm{Dc}=$ climatic drivers $\mathrm{P}=$ pressures, $\mathrm{Ss}=$ socio-economic state, $\mathrm{Se}=$ environmental state, $\mathrm{I}=$ impact, $\mathrm{RCBG}=$ capacity building and governance responses, RIM = institutional measure responses, RLI = livelihood intervention responses, $\mathrm{REI}=$ environmental intervention responses.

On the other hand, response indicators such as livelihood and environmental intervention responses were positive and significant $(p<0.05)$, suggesting that these indicators positively influenced the lake ecosystem resilience.

\section{Discussion}

\subsection{Drivers and Pressures}

This study depicts the drivers, pressures, states, impacts, and responses that influence the resilience of inland tropical freshwater shallow lakes' ecosystems. Among the drivers, rapid population growth has resulted in multiple pressures that degrade the state of the Lake Malombe ecosystem. Evidence shows that in 1998 the western bank of Lake Malombe had 8400 households and the eastern bank had 2657 [32]. Using the Malawi national average household size of a five-person per household, the total population in 1998 was estimated at 42,000 on the west bank and 13,285 on the east bank [67]. Factor in $3 \%$ annual 
population growth rate for Mangochi district [38], and the projected population in 2020 was estimated at 82,891 on the west bank and 25,657 households on the east bank. However, the FISH project report revealed that the population trend in the South East Arm where Lake Malombe is located has increased from 295,891 in 1998 to 404,850 in 2008 [27]-making it one of the most densely populated areas (average of over 500 people $/ \mathrm{km}^{2}$ ) in Malawi. This demographic trend is linked to poverty [33]. The 2011 integrated household survey ranked Mangochi, where Lake Malombe is located, as second among the top four districts (Machinga, Balaka, and Zomba) in Malawi with the highest rates of poverty (0.13 USD/day) and first in terms of the rate of ultra-poor residents (0.08 USD/day) - compared to the national average of 2 USD/day) [33]. Approximately $99 \%$ of the local population in the catchment area predominantly depend on fishing for their sustenance [35]. Other sources of income include fish sales from aquaculture, cash crops, rainfed and irrigated food crops, employment, rentals, non-farm businesses, and others. The daily income generated from these socio-economic activities is less than 2 USD/day with the exception of fishery (Figure 10a).

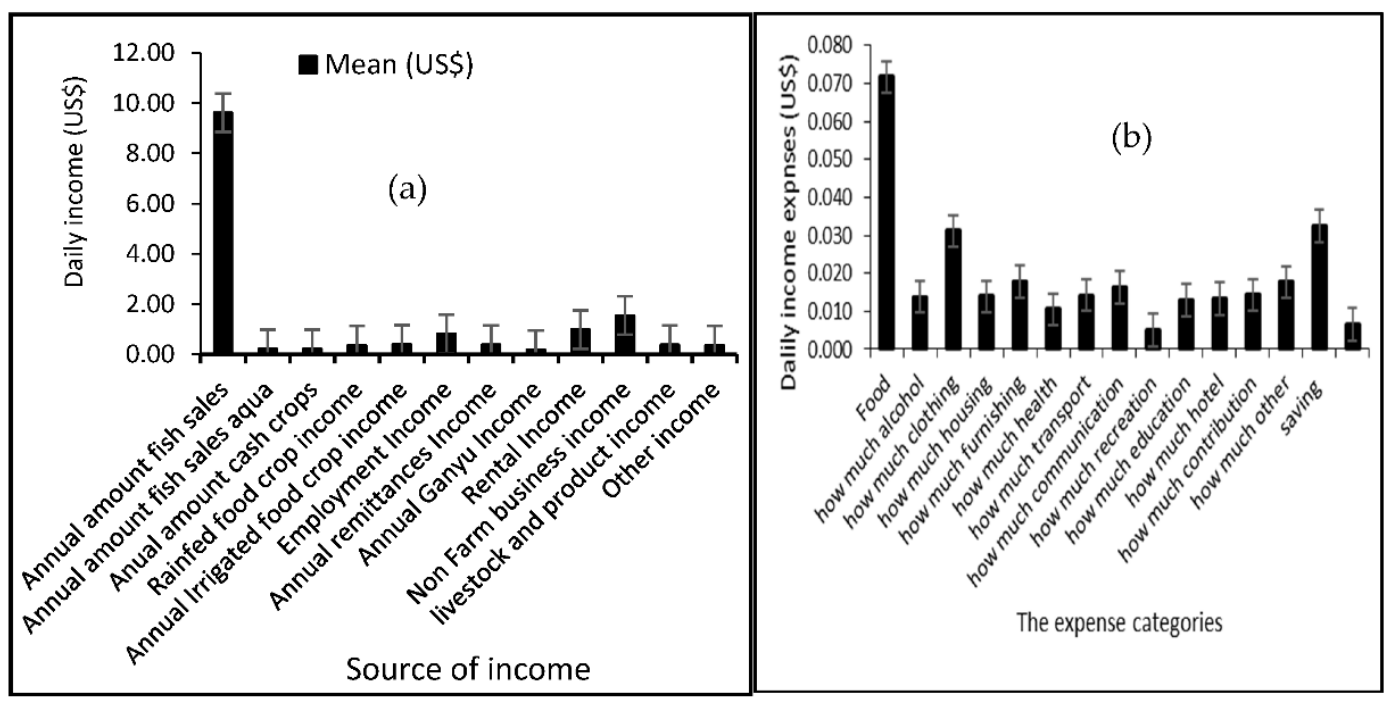

Figure 10. Driving forces of Lake Malombe ecosystem dynamics. (a) source of income (b) the expense categories.

The expenses in Figure 10b indicate that income is spent mostly on food, while saving is the least common use of money-indicating the local population's socio-economic trap. In the Lake Malombe context, the socio-economic trap is where the local population has limited alternatives to mobilize adequate resources to overcome the shocks and remain in the poverty trap $[35,68]$. The overall household income is less than 1 USD per day (Figure 10a). The Lake Malawi Basin Program Integrated Household Survey in 2008 put it at 0.74 USD per day, suggesting that the local population's over-dependence on lake resources is triggered by poverty and a lack of alternative livelihood options [52,69]. Sandhu \& Sandhu [69] and Suich et al. [70] demonstrated the link between poverty and the ecosystem's resilience. In the Lake Malombe context, poverty pushes vulnerable individuals to desperately over-depend on the lake and exploit even those resources deemed conserved for future generations [35]. This is also the typical scenario in African Great Rift Valley lakes where over-exploitation of lake ecosystem resources is extensive [71], triggering a multitude of direct effects on the riparian populations while undermining the capacity of the lake ecosystem resources to support human livelihoods [71] continuously. The increase in vertical and horizontal effort is associated with poverty, rapid population growth, and a lack of adaptation strategies to the changing ecosystem [31]. The decline in fish biomass landings reported by Makwinja et al. [41] suggests that vertical fishing effort triggered the lake ecosystem dynamics, which eventually leads to over-exploitation of the resource, 
leading to socio-economic struggles. The scenario depicted in this study is expected in African freshwater ecosystems where poor and economically vulnerable social groups exploit the ecosystems, either as fisherfolks, crew members, or traders [72,73].

Lake Malombe is categorized as one of the areas in Malawi susceptible to climatic variability. The eastern part of the lake is a drought-prone area [32]. Dry spells and floods in the past have had substantial socio-ecological impacts on the lake ecosystem and the local communities in Lake Malombe [32]. The Lake Malombe hydrological regime indicates that it is shaped by extreme weather events such as increased rainfall, prolonged drought, and temperature fluctuation, which consequently threaten socio-ecological components such as livelihood, aquatic vegetation, and biodiversity [74]. Christia et al. [74] and Thanh et al. [75] have pointed out that increased rainfall variability affects water quality, toxic bacteria blooms, and dissolved nutrient concentration, spreading water-borne diseases. Unexpected extreme weather events such as heavy rains, drought, and rising temperatures add more pressure on the existing challenges such as declining ecosystem productivity, soil fertility, water quality degradation, toxic bacteria blooms, and dissolved nutrient concentration, consequently spreading water-borne diseases [75]. The findings align with what Njaya et al. [40], Okpara et al. [76], Lemoalle et al. [77], Likoya [78], Limuwa et al. [79], and Desta [80] reported in Lake Chilwa, the Shire River Basin, and Lake Malawi in Malawi. Cowx and Aya [81], Jamu et al. [31], Wood et al. [82], Dulanya et al. [26], Makwinja et al. [23], Williams et al. [83], and Nkwanda et al. [84] also pointed out the same scenarios in Chia Lagoon, Central Malawi, Lake Chilwa in Southern Malawi, and the Lilongwe River Basin. Guo et al. [85] also demonstrated how human activities such as draining inland freshwater shallow lakes and land use transformation in the basin influenced seasonal flooding in the Poyang Lake basin in China. In West Africa, Li et al. [86] demonstrated how human activities such as landscape alteration in Niger and the Lake Chad basin are strongly linked to changes in hydrological regimes at the watershed scale, leading to a disproportionately large impact on water balance. Elias et al. [83] linked aggressive agricultural expansion to the collapse of the lake ecosystem of the Ethiopia Central Rift Valley. Agricultural development has been identified as putting significant pressure on the mangrove ecosystem [87]. In the Southern Part of the Andaman Islands, about $6 \mathrm{~km}^{2}$ of mangroves were cleared out during the last three decades (1979-2013) for fishing, severely impacting the mangrove ecosystem and biodiversity. In Malaysia, human encroachment, agriculture, and coastal erosion have been identified as putting pressure on freshwater ecosystems [54].

\subsection{State and Impacts}

Human and environmental drivers, alongside other pressures occurring across multiple scales, have shaped the current state of the Lake Malombe ecosystem (Figure 11). Increased phytoplankton production, invasion of alien species, water quality degradation, drying up of rivers, over-exploitation of fisheries, increased erosion, shrinking of the lake, and a catastrophic decline in fish stocks, as reported by Hara [88], Dulanya et al. [26], Froese et al. [89], and Makwinja et al. [35], have depressed the lake ecosystem's resilience. The depletion of high trophic level fish species in the 1980s led to what can be described as top-down cascading effects of human food web alterations [37] - a common scenario in many African inland freshwater shallow lakes' ecosystems [90-92]. 


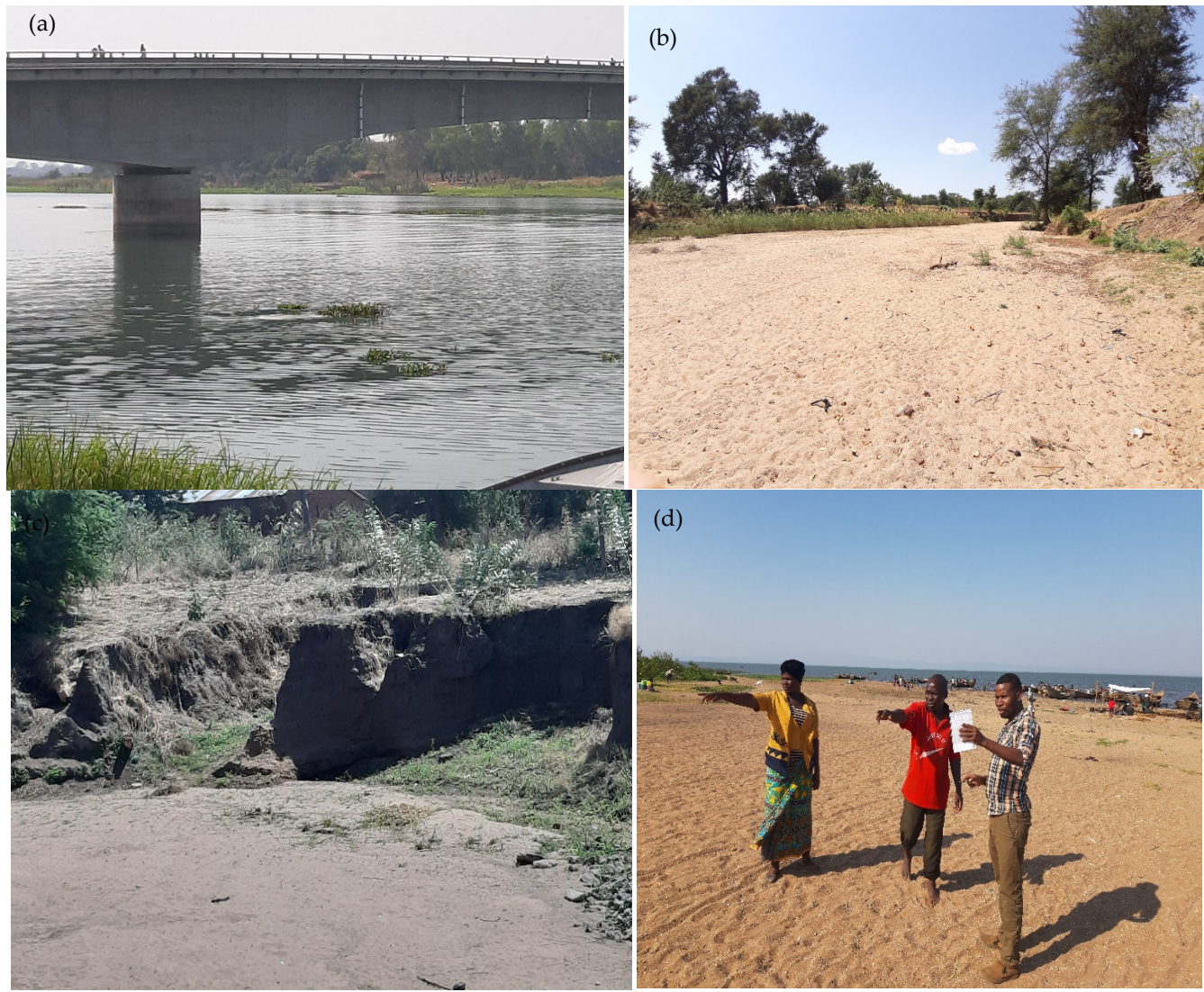

Note: Photo (a) was taken in the upper Shire River that connects Lake Malawi to Lake Malombe and shows water hyacinth driven towards Lake Malombe. Picture (b) shows the drying river in the west part of Lake Malombe catchment. Picture (c) shows the degraded river banks. Picture (d) shows the shrinking Lake Malombe. All photos except (d), which Emmanuel Chisesa took, were taken by Rodgers Makwinja during field observations.

Figure 11. The current state of the Lake Malombe ecosystem.

The impact indicator in this study is contributed to by severe biodiversity loss, local communities' exposure to vulnerability, population displacement, increased crime rates, a socio-economic trap, HIV / AIDs prevalence, hunger, disease outbreak, decreasing ecosystem provisioning services (EPSs), reduced climate regulation, reduced supporting services, decreasing biodiversity, and a loss of genetic diversity. Increased removal of mangroves, habitat degradation, fishing efforts, extreme lake level decreases, and rivers' drying up [31] are linked to declining fish biomass and loss of revenue, and this has widened the socioeconomic gap between the poor and the rich, as demonstrated by the Gini coefficient of 5.6 and an average income of 1.74 USD per household per day [33]. Diseases such as diarrhea, dysentery, and schistosomiasis are common, particularly in the flooded areas of Lake Malombe. Figure 12a shows that water-borne diseases such as diarrhea are the most prominent, followed by dysentery and then schistosomiasis. Figure $12 \mathrm{~b}$ shows that drought, floods, heavy storms, and dry spells are more prevalent in the three traditional authorities around Lake Malaombe.

Schistosomiasis in Lake Malombe is linked to a declining population of molluscivorous fishes (Mylochromis spp., and Tramatocranus placodon) due to human and environmental pressures, which enables Bulinus nyassanus (the host of human urinary schistosomes) to survive in open waters [93]. Diarrhea and dysentery are highly linked to a decline in forest and shrubland leading to increased seasonal flooding and water pollution. Similar cases are reported in the Lake Chilwa Basin [94], Tonle Sap Lake in Cambodia [95], and Lake Malawi [40]. Makwinja et al. [5] estimated that Lake Malombe lost approximately 8.92 million USD in revenue from fishing within the period from 1982 to 2019 and about 79.83 million USD from 1999 to 2019 due to landscape transformation. In line with these 
findings, Malawi is currently losing approximately 93 million USD annually due to a decline in ecosystem service functions and unsustainable use of biodiversity [96].

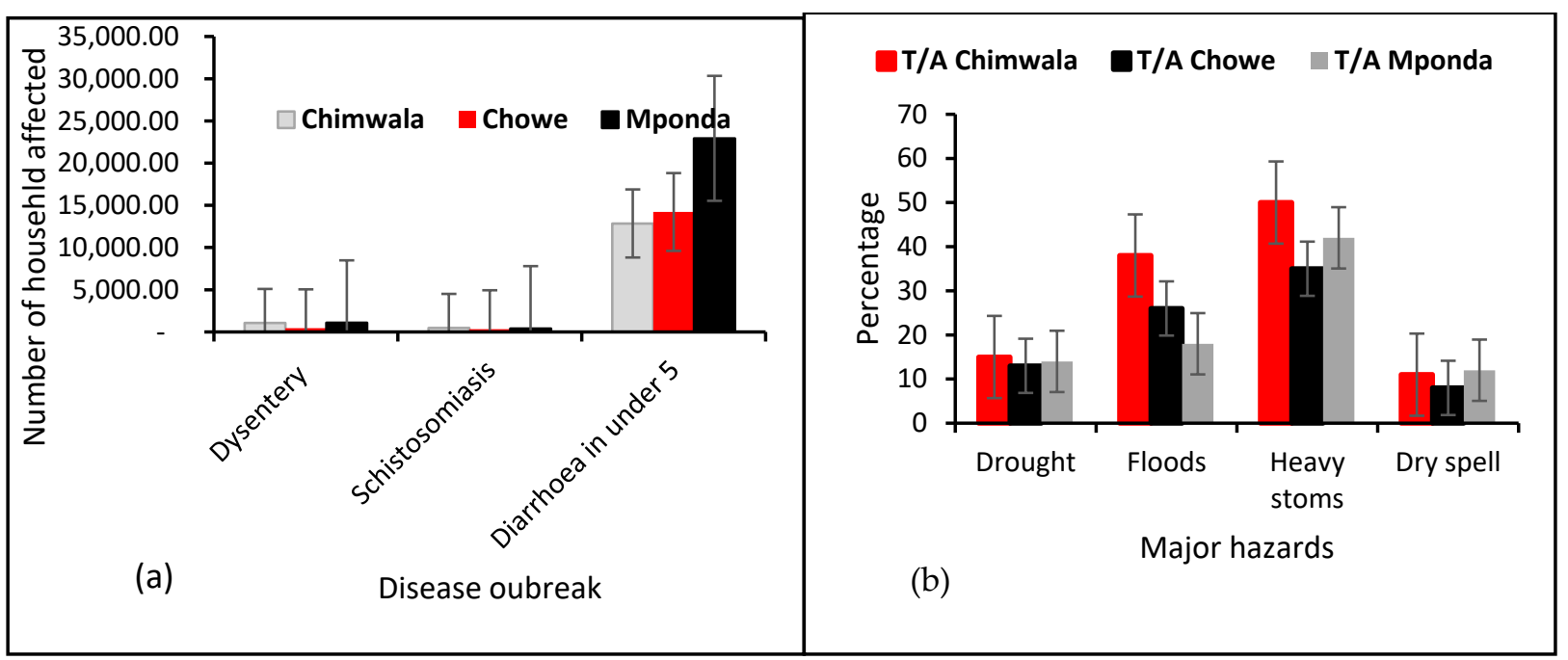

Figure 12. Lake Malombe disease outbreak and significant hazards. (a) Disease oubreak. (b) Major hazards.

\subsection{Response}

Response in this study refers to the actions adopted by the decision-makers, managers, and local communities to reverse the situation [97]. Figure 4 categorized the responses into an institutional framework consisting of livelihood intervention and environmental intervention. The institutional framework refers to the government policies and other related legal frameworks formulated to manage freshwater ecosystem service functions in Malawi. The Fisheries Act contains regulations that aim to maximize fishery production with a maximum sustainable yield (MSY) as a reference point. The Fisheries Department, through this act, enforces a closed season, minimum mesh size, licensing, gear restriction, and habit protection in Lake Malombe. However, the challenge is that the act focuses on reducing the vertical and horizontal fishing effort to manage Oreochromis species. Other existing threats, such as the declining population of the potamodromous (O. microlepis), the commercial extinction of L. mesops, the impacts of climate change, and the effect of siltation on fish biodiversity, are given low priority [31]. The command-control nature of the act also makes it costly and challenging to implement due to increased non-compliance and strong resistance from the local fishing communities [98]. Again, Lake Malombe's ecosystem health is shaped by multiple interactions between socio-ecological components rather than a single factor; hence, the Fisheries Act alone cannot effectively reverse the situation. Other related policies such as forestry, water, land, wildlife, irrigation, and tourism formulated to safeguard biodiversity and the lake ecosystem lack synergy and have conflicting key priorities that compromise the conservation effort. National Climate Change Management and fisheries policies do not explicitly explain how the lake ecosystem can withstand the shocks instigated by decreasing water levels due to rainfall fluctuation and drought, which cause the disappearance of aquatic vegetation, reducing fish breeding areas and biodiversity. Illegal exploitation of lake ecosystem resources in Lake Malombe is complex and often driven by economic, social, and instructional factors. For example, increased poverty fuels illegal exploitation of the lake's resources. Limited funding, the lack of a robust governance system, increased corruption, and inadequate monitoring and enforcement leave the conservation managers few options to address the lake ecosystem challenges. Livelihood and environmental intervention refer to the projects aimed at reducing the local population's over-dependence on the lake ecosystem services while stimulating their participation in conservation. In Lake Malombe, promoting aquaculture 
and income-generating activities such as craft-making and bee-keeping as a substitute for expanding farming around Lake Malombe, charcoal production, and artisanal fishing have been used as livelihood interventions. However, the challenges of these interventions involve the current competing interests among the implementers. Data on the effectiveness and success of these projects have also been scarce, making it difficult to track the progress and their impacts. Environmental intervention refers to those projects focused on ecological restoration and climate change resilience. The success of these interventions depends on how the local population embraces these socio-ecological governance systems and policy reforms. If the communities fail to generate sufficient income from the interventions, they eventually return to lake resource over-exploitation. Figure 8 demonstrates that although the response (R) factor increased slowly, it was the lowest among all indicators, suggesting that the current interventions are inadequate to reverse the situation in Lake Malombe.

\subsection{Lake Malombe Ecosystem Resilience and Influencing Factor}

Resilience is the ability of the lake to maintain a state of equilibrium after being subjected to external or internal stressors [99]. The freshwater lakes' resilience follows a nonlinear pattern in which perturbations such as drivers, pressures, and impacts move the lakes away from their natural state, but after interventions the balance is restored and the ecosystem returns to its normal state. Lake Malombe, like any other freshwater lake, can maintain its natural ecological state when exposed to drivers, pressures, impacts, and responses. What can be inferred from Figure 9 is that the lake ecosystem resilience is falling away from its natural state due to increasing rates of drivers, pressures, states, and impactsan indicator of the lake ecosystem's deterioration. Similar scenarios have been reported in China [100], New Zealand [101], and the Mekong river in China, Myanmar, Thailand, Lao PDR, Cambodia, and Vietnam [102]. The effect of demographic, socio-economic, and climatic factors as drivers, pressures, and environmental states were significant $(p<0.05)$ and negative, suggesting that these indicators negatively influenced the lake ecosystem resilience and contributed to its degradation. A similar scenario is depicted in Infranz Wetland, Ethiopia [103] and Dianchi Lake in China [59]. Few response indicators such as livelihood and environmental intervention were positive and significant $(p<0.05)$, suggesting that these indicators slighltly influence the state of the lake ecosystem positively. Although multiple measures have been taken to conserve and protect the lake ecosystem, the results show that there is still much to achieve sustainability and attain the ideal state of the Lake Malombe ecosystem.

As seen in Figures 6 and 7, the steady increase in drivers, pressures, and impacts pushes the lake ecosystem to a deteriorated state. The deteriorated lake ecosystem often shows resilience to restoration activities as strong internal positive feedback loops need to overcome the stressors characterized by internal feedback loops that keep the lake in its state of equilibrium. It has been argued that maintaining the lake ecosystem resilience at a desirable state is the most pragmatic and practical approach to managing the inland freshwater shallow lake ecosystems. Unfortunately, many African freshwater lakes depict the other side of the story. About $40-90 \%$ of the shallow lakes in East Africa have dramatically shrunk - the same scenario reported in Lake Chilwa, Lake Chiuta, and other satellite lakes in Malawi $[32,38,104]$. Figure 9 further shows that the risk index in the Lake Malombe ecosystem reached its worst level between the 1990 and 2000-as evidenced by a lower index value, which indicates the worsening condition of the lake ecosystem. A similar observation was made in New Zealand [101]. Based on the interviews, the responses to the current state of the lake ecosystem in Lake Malombe are hampered by institutional capacities such as lack of funds and training and inadequate technical staff. These limitations are the leading cause of inadequate management plans and strategies for improving the current lake ecosystem's state. Additionally, the continuous removal of forest and grass for farming, fuel, settlements, and construction materials in the upland areas of the catchment will only continue to degrade the lake catchment beds, which are the recipients of debris during the heavy siltation brought by intense precipitation. 


\section{Conclusions}

This study used DPSIR and Tobit models to demonstrate that the state of the Lake Malombe ecosystem is declining, and its vulnerability is linked to demographic, socioeconomic, and climatic drivers. It explored the relevant drivers, pressures, states, impacts, and response indicators that are helpful when making management decisions and formulating long-term policy-focused responses. The study further demonstrates that the lake ecosystem resilience is falling away from its natural state due to the increasing rates of drivers, pressures, states, and impacts-an indicator of the lake ecosystem's deterioration and a demonstration of how the top-down processes are gradually eroding the lake ecosystem's health. The study demonstrates that substantial freshwater ecosystem management under the current scenario requires a long-term, resilient sustainability plan. This can be achieved through individual and collective efforts. Medium and long-term conservation efforts and environmental and livelihood projects can help to reduce poverty and over-dependence on the lake ecosystem. The institutional measures for tackling lake resource exploitation should also be adjusted promptly through a series of response measures by local authorities, the local population, and conservation agencies. Challenges related to sedimentation, aquatic biodiversity losses, and water quality degradation require an effective, integrated lake basin restoration programs. There is also a need to integrate different policies relating to land, fisheries, wildlife, climate change, tourism, irrigation, agriculture, food security, and national population to achieve the goal of a sustainable integrated freshwater ecosystem. This integration will help to reduce the existing threats to the lake ecosystem service functions such as cultivation and the conversion of forests, wetlands, and river banks into farmland, which are driven by rapid population growth and poverty.

Author Contributions: R.M. conceptualized the study, developed the methodology, sourced the data, analyzed the data, and developed the original manuscript. S.M., C.C.K., E.K., I.B.M.K., T.A. and F.N. supervised the study, reviewed and edited the manuscript, and visualized and validated the study. All authors have read and agreed to the published version of the manuscript.

Funding: This project was funded by the African Centre of Excellence for Water Management (ACEWM) through the World Bank's African Centres of Excellence (ACE II) Project, grant number GSR/9316/11.

Institutional Review Board Statement: Not applicable.

Informed Consent Statement: Not applicable.

Data Availability Statement: The datasets analyzed during the current study are available from the corresponding author upon reasonable request.

Acknowledgments: The authors wish to thank the Malawi University of Business and Applied Sciences for providing financial support towards the publication of this paper.

Conflicts of Interest: The authors of this paper declare that there are no conflict of interest.

\section{References}

1. Reid, A.J.; Carlson, A.K.; Creed, I.F.; Eliason, E.J.; Gell, P.A.; Johnson, P.T.J.; Kidd, K.A.; MacCormack, T.J.; Olden, J.D.; Ormerod, S.J.; et al. Emerging threats and persistent conservation challenges for freshwater biodiversity. Biol. Rev. 2019, 94, 849-873. [CrossRef] [PubMed]

2. Ho, L.; Goethals, P. Opportunities and Challenges for the Sustainability of Lakes and Reservoirs in Relation to the Sustainable Development Goals (SDGs). Water 2019, 11, 1462. [CrossRef]

3. Duggan, I.; Rixon, C.; Maclssac, H. Popularity and propagule pressure: Determinants of introduction and establishment of aquarium fish. Biol. Invasion 2006, 8, 377-382. [CrossRef]

4. Martins, J.; Camanho, M.; Gaspar, M. A review of the application of driving forces-Pressure-State-Impact-Response framework to fisheries management. Ocean Coast. Manag. 2012, 69, 273-281. [CrossRef]

5. Makwinja, R.; Kaunda, E.; Mengistou, S.; Alamirew, T. Impact of land use/land cover dynamics on ecosystem service value-A case from Lake Malombe, Southern Malawi. Environ. Monit. Assess. 2021, 193, 1-23. [CrossRef]

6. Fetahi, T. Eutrophication of Ethiopian water bodies: A serious threat to water quality, biodiversity, and public health. Afr. J. Aquat. Sci. 2019, 44, 303-312. [CrossRef] 
7. Olaka, L.A.; Ogutu, J.O.; Said, M.Y.; Oludhe, C. Projected Climatic and Hydrologic Changes to Lake Victoria Basin Rivers under Three RCP Emission Scenarios for 2015-2100 and Impacts on the Water Sector. Water 2019, 11, 1449. [CrossRef]

8. Ogutu-Ohwayo, R.; Hecky, R.E.; Cohen, A.S.; Kaufman, L. Human impacts on the African Great Lakes. Environ. Boil. Fishes 1997, 50, 117-131. [CrossRef]

9. Njiru, J.; van der Knaap, M.; Kundu, R.; Nyamweya, C. Lake Victoria fisheries: Outlook and management. Lakes Reserv. 2018, 23, 52-162. [CrossRef]

10. Dersseh, M.G.; Kibret, A.A.; Tilahun, S.A.; Worqlul, A.W.; Moges, M.A.; Dagnew, D.C.; Abebe, W.B.; Melesse, A.M. Potential of Water Hyacinth Infestation on Lake Tana, Ethiopia: A Prediction Using a GIS-Based Multi-Criteria Technique. Water 2019, 11, 1921. [CrossRef]

11. IPBES. Summary for Policymakers of the Global Assessment Report on Biodiversity and Ecosystem Services of the Intergovernmental Science-Policy Platform on Biodiversity and Ecosystem Services; IPBES: Bonn, Germany, 2019.

12. Earles, J.M.; Yeh, S.; Skog, K.E. Timing of carbon emissions from global forest clearance. Nat. Clim. Chang. 2012, 2, 682-685. [CrossRef]

13. Makwinja, R.; Mengistou, S.; Kaunda, E.; Alamirew, T. Land use/land cover dynamics, trade-offs and implications on tropical inland shallow lakes' ecosystems' management: Case of Lake Malombe, Malawi. Sustain. Environ. 2021, 7, 1969139. [CrossRef]

14. Bi, W.; Weng, B.; Yuan, Z.; Ye, M.; Zhang, C.; Zhao, Y.; Yan, D.; Xu, T. Evolution Characteristics of Surface Water Quality Due to Climate Change and LUCC under Scenario Simulations: A Case Study in the Luanhe River Basin. Int. J. Environ. Res. Public Health 2018, 15, 1724. [CrossRef] [PubMed]

15. Miles, A.; DeLonge, M.S.; Carlisle, L. Triggering a positive research and policy feedback cycle to support a transition to agroecology and sustainable food systems. Agroecol. Sustain. Food Syst. 2017, 41, 855-879. [CrossRef]

16. Yang, X.-E.; Wu, X.; Hao, H.-L.; He, Z.-L. Mechanisms and assessment of water eutrophication. J. Zhejiang Univ. Sci. B 2008, 9 , 197-209. [CrossRef] [PubMed]

17. Davidson, N.C.; Finlayson, C.M. Extent, regional distribution and changes in area of different classes of wetland. Mar. Freshw. Res. 2018, 69, 1525. [CrossRef]

18. Makwinja, R.; Kosamu, I.B.M.; Kaonga, C.C. Determinants and Values of Willingness to Pay for Water Quality Improvement: Insights from Chia Lagoon, Malawi. Sustainability 2019, 11, 4690. [CrossRef]

19. Li, Y.; Zhang, Z.; Shi, M. Restrictive Effects of Water Scarcity on Urban Economic Development in the Beijing-Tianjin-Hebei City Region. Sustainability 2019, 11, 2452. [CrossRef]

20. Ogutu-Ohwayo, R.; Balirwa, J. Management challenges of freshwater fisheries in Africa. Lakes Reserv. Res. Manag. 2006, 11, 215-226. [CrossRef]

21. Hall, N.D.; Stuntz, B.B.; Abrams, R.H. Climate Change and Freshwater Resources. Nat. Resour. Environ. 2008, $22,30-35$.

22. Djoudi, H.; Brockhaus, M.; Locatelli, B. Once there was a lake: Vulnerability to environmental changes in northern Mali. Reg. Environ. Change 2013, 13, 493-508. [CrossRef]

23. Makwinja, R.; Chapotera, M.; Likongwe, P.; Banda, J.; Chijere, A. Location and Roles of Deep Pools in Likangala River during 2012 Recession Period of Lake Chilwa Basin. Int. J. Ecol. 2014, 2014, 294683. [CrossRef]

24. Magrin, G. The disappearance of Lake Chad: History of a myth. J. Political Ecol. 2016, 23, 205-222. [CrossRef]

25. Jones, E.R.; O’Flynn, H.; Njoku, K.; Crosbie, E.J. Detecting endometrial cancer. Obstet. Gynaecol. 2021, 23, 103-112. [CrossRef]

26. Dulanya, Z.; Croudace, I.; Reed, J.; Trauth, M. Palaeoliminological reconstruction of recent environmental change in Lake Malombe (S. Malawi) using multiple proxies. Water SA 2014, 40,717-728. [CrossRef]

27. Okech, E.; Kitaka, N.; Omondi, S.; Verschuren, D. Water level fluctuations in Lake Baringo, Kenya, during the 19th and 20th centuries: Evidence from lake sediments. Afr. J. Aquat. Sci. 2019, 44, 25-33. [CrossRef]

28. Bootsma, H.; Hecky, R. The major socio-economic benefits from these three major African conservation of the African Great Lakes: A Limnological Perspective. Conserv. Biol. 1993, 7, 644-656. [CrossRef]

29. Jordaan, M.; Chakona, A. Protected Areas and Endemic Freshwater Fishes of the Cape Fold Ecoregion: Missing the Boat for Fish Conservation? Front. Environ. Sci. 2020, 8, 502042. [CrossRef]

30. Swallow, B.M.; Sang, J.; Nyabenge, M.; Bundotich, D.K.; Duraiappah, A.K.; Yatich, T.B. Tradeoffs, synergies and traps among ecosystem services in the Lake Victoria basin of East Africa. Environ. Sci. Policy 2009, 12, 504-519. [CrossRef]

31. Jamu, D.; Banda, M.; Njaya, F.; Hecky, R.E. Challenges to sustainable management of the lakes of Malawi. J. Great Lakes Res. 2011, 37, 3-14. [CrossRef]

32. FISH. Environmental Threats and Opportunities Assessment (ETOA) of Four Major Lakes in Malawi; USAID/FISH Project; Pact Publication: Lilongwe, Malawi, 2015.

33. Makwinja, R.; Kaunda, E.; Mengistou, S.; Alemiew, T.; Njaya, F.; Kosamu, I.B.M.; Kaonga, C.C. Lake Malombe fishing communities' livelihood, vulnerability, and adaptation strategies. Curr. Res. Environ. Sustain. 2021, 3, 100055. [CrossRef]

34. Makwinja, R.; Mengistou, S.; Kaunda, E.; Alamirew, T. Lake Malombe fish stock fluctuation: Ecosystem and fisherfolks. Egypt. J. Aquat. Res. 2021, 47, 321-327. [CrossRef]

35. Makwinja, R.; Mengistou, S.; Kaunda, E.; Alamirew, T. Economic value of tropical inland freshwater shallow lakes: Lesson from Lake Malombe, Malawi. Afr. J. Ecol. 2021, 29, 1-15. [CrossRef]

36. Hara, M.; Njaya, F. Between a rock and a hard place: The need for and challenges to implementation of Rights-Based Fisheries Management in small-scale fisheries of southern Lake Malawi. Fish. Res. 2016, 174, 10-18. 
37. Makwinja, R.; Mengistou, S.; Kaunda, E.; Alamirew, T. Spatial distribution of zooplankton in response to ecological dynamics in tropical shallow lake: Insight from Lake Malombe, Malawi. J. Freshw. Ecol. 2021, 36, 127-147. [CrossRef]

38. Government of Malawi. Mangochi District State of Environment and Outlook; Mangochi District Council: Mangochi, Malawi, 2014.

39. Njaya, F. Ecosystem approach to fisheries in southern Lake Malawi: Status of the fisheries co-management. Aquat. Ecosyst. Health Manag. 2018, 21, 159-167. [CrossRef]

40. Njaya, F.; Donda, S.; Béné, C. Analysis of Power in Fisheries Co-Management: Experiences from Malawi. Soc. Nat. Resour. 2012, 25, 652-666. [CrossRef]

41. Makwinja, R.; Mengistou, S.; Kaunda, E.; Alemiew, T.; Phiri, T.; Kosamu, I.; Kaonga, C. Modeling of Lake Malombe Annual Fish Landings and Catch per Unit Effort (CPUE). Forecasting 2021, 3, 39-55. [CrossRef]

42. Mandić, A. Structuring challenges of sustainable tourism development in protected natural areas with driving force-pressurestate-impact-response (DPSIR) framework. Environ. Syst. Decis. 2020, 40, 560-576. [CrossRef]

43. Tscherning, K.; Helming, K.; Krippner, B.; Sieber, S.; Paloma, S.G.Y. Does research applying the DPSIR framework support decision making? Land Use Policy 2012, 29, 102-110. [CrossRef]

44. Rodrigues, J.M.G. Cultural Services in Aquatic Ecosystems. In Ecosystem Services and River Basin Ecohydrology; Springer: Dordrecht, The Netherlands, 2015; pp. 35-56.

45. Nguyen, A.T.; Hens, L. Human Ecology of Climate Change Hazards: Concepts, Literature Review, and Methodology. In Human Ecology of Climate Change Hazards in Vietnam; Springer: Cham, Switzerland, 2018; pp. 3-36.

46. Ma, X.; Wang, C.; Yu, Y.; Li, Y.; Dong, B.; Zhang, X.; Niu, X.; Yang, Q.; Chen, R.; Li, Y.; et al. Ecological efficiency in China and its influencing factors-a super-efficient SBM metafrontier-Malmquist-Tobit model study. Environ. Sci. Pollut. Res. 2018, 25, 20880-20898. [CrossRef]

47. Gabrielsen, P.; Bosch, P. Internal Working Paper Environmental Indicators: Typology and Use in Reporting; European Environment Agency: Copenhagen, Denmark, 2003.

48. Millennium Ecosystem Assessment. Ecosystems and Human Well-Being: Synthesis; Island Press: Washington, DC, USA, 2005.

49. Friend, A.; Rapport, D. Evolution of macro-information systems for sustainable development. Ecol. Econ. 1991, 3, 59-76. [CrossRef]

50. Borja, Á.; Galparsoro, I.; Solaun, O.; Muxika, I.; Tello, E.M.; Uriarte, A.; Valencia, V. The European Water Framework Directive and the DPSIR, a methodological approach to assess the risk of failing to achieve good ecological status. Estuar. Coast. Shelf Sci. 2006, 66, 84-96. [CrossRef]

51. Mangi, S.C.; Roberts, C.M.; Rodwell, L.D. Reef fisheries management in Kenya: Preliminary driver-pressure-state-impactsresponse (DPSIR). Ocean Coast. Manag. 2007, 50, 463-480.

52. Bell, R.J.; Collie, J.S.; Jamu, D.; Banda, M. Changes in the biomass of chambo in the southeast arm of Lake Malawi: A stock assessment of Oreochromis spp. J. Great Lakes Res. 2012, 38, 720-729. [CrossRef]

53. Pinto, R.; de Jonge, V.; Neto, J.; Domingos, T.; Marques, J.; Patrício, J. Towards a DPSIR driven integration of ecological value, water uses and ecosystem services for estuarine systems. Ocean Coast. Manag. 2013, 72, 64-79. [CrossRef]

54. Sarmin, N.; Hasmadi, I.M.; Pakhriazad, H.; Khairil, W. The DPSIR framework for causes analysis of mangrove deforestation in Johor, Malaysia. Environ. Nanotechnol. Monit. Manag. 2016, 6, 214-218. [CrossRef]

55. Gari, S.R.; Guerrero, C.E.O.; A-Uribe, B.; Icely, J.D.; Newton, A. A DPSIR-analysis of water uses and related water quality issues in the Colombian Alto and Medio Dagua Community Council. Water Sci. 2018, 32, 318-337. [CrossRef]

56. Zare, F.; Elsawah, S.; Bagheri, A.; Nabavi, E.; Jakeman, A.J. Improved integrated water resource modelling by combining DPSIR and system dynamics conceptual modelling techniques. J. Environ. Manag. 2019, 246, 27-41. [CrossRef] [PubMed]

57. Gebremedhin, S.; Getahun, A.; Anteneh, W.; Bruneel, S.; Goethals, P. A Drivers-Pressure-State-Impact-Responses Framework to Support the Sustainability of Fish and Fisheries in Lake Tana, Ethiopia. Sustainability 2018, 10, 2957. [CrossRef]

58. Government of Malawi. Review of Decentralized Environment Management Guidelines; Ministry of Local Government and Rural Development: Lilongwe, Malawi, 2011.

59. Wang, Z.; Zhou, J.; Loaiciga, H.; Guo, H.; Hong, S. A DPSIR Model for Ecological Security Assessment through Indicator Screening: A Case Study at Dianchi Lake in China. PLoS ONE 2015, 10, e0131732. [CrossRef] [PubMed]

60. Niemeijer, D.; de Groot, R. Framing environmental indicators: Moving from causal chains to causal networks. Environ. Dev. Sustain. 2008, 10, 89-106. [CrossRef]

61. Carr, E.; Wingard, P.M.; Yorty, S.C.; Thompson, M.C.; Jensen, N.K.; Roberson, J. Applying DPSIR to sustainable development. Int. J. Sustain. Dev. World Ecol. 2007, 14, 543-555. [CrossRef]

62. Heal, G. Valuing ecosystem services. Ecosystems 2000, 3, 24-30. [CrossRef]

63. Svarstad, H.; Kjeruff, P.; Rothman, D.; Sieple, H.; Watzold, F. Discursive biases of the environmental research framework DPSIR. Land Use Policy 2008, 25, 116-125.

64. Jury, M.R. Malawi's Shire River Fluctuations and Climate. J. Hydrometeorol. 2014, 15, 2039-2049. [CrossRef]

65. Zhang, D.; Shen, J.; Sun, F. Evaluation of Water Environment Performance Based on a DPSIR-SBM-Tobid Model. Water Resour. Hydrol. Eng. 2020, 24, 1641-1654.

66. Amore, M.; Murtinu, S. Tobit models in strategy research: Critical issues and applications. Glob. Strategy J. 2021, 11, $331-355$. [CrossRef] 
67. Hara, M.; Jul-Larsen, E. The "Lords" of Malombe; An Analysis of Fishery Development and Changes in Fishing Effort on Lake Malombe, Malaw1. In Management, Co-Management or no Management? Major Dilemas in Southern African Freshwater Fisheries; Food and Agriculture Organisation of the United Nations: Rome, Italy, 2003; pp. 179-201.

68. Salas, S.; Bjørkan, M.; Bobadilla, F.; Cabrera, M.A. Addressing Vulnerability: Coping Strategies of Fishing Communities in Yucatan, Mexico. In Poverty Mosaics: Realities and Prospects in Small-Scale Fisheries; Springer: Cham, The Switzerland, $2011 ;$ pp. 195-220.

69. Sandhu, H.; Sandhu, S. Poverty development, and Himalayan ecosystems. AMBIO 2015, 44, 297-307. [CrossRef] [PubMed]

70. Suich, H.; Howe, C.; Mace, G. Ecosystem services and poverty alleviation: A review of the empirical links. Ecosyst. Serv. 2015, 12, 137-147. [CrossRef]

71. Cawthorn, D.; Hoffman, L. The bushmeat and food security nexus: A global account of the contributions, conundrums, and ethical collisions. Food Res. Int. 2015, 76, 906-925.

72. Welcomme, R.; Cowx, I.; Coates, D.; Béné, C.; Simon, F.; Ashley, H.; Kai, L. Inland capture fisheries. Philos. Trans. R. Soc. B 2010, 365, 2881-2896. [CrossRef] [PubMed]

73. Nagoli, J.; Mulwafu, W.; Green, E.; Likongwe, P.; Chiwona-Karltun, L. Conflicts over Natural Resource Scarcity in the Aquatic Ecosystem of the Lake Chilwa. Environ. Ecol. Res. 2016, 4, 207-216. [CrossRef]

74. Christia, C.; Giordani, G.; Papastergiadou, E. Environmental Variability and Macrophyte Assemblages in Coastal Lagoon Types of Western Greece (Mediterranean Sea). Water 2018, 10, 151. [CrossRef]

75. Thanh, H.T.; Tschakert, P.; Hipsey, M.R. Tracing environmental and livelihood dynamics in a tropical coastal lagoon through the lens of multiple adaptive cycles. Ecol. Soc. 2020, 25, 31. [CrossRef]

76. Okpara, U.T.; Stringer, L.C.; Dougill, A.J.; Bila, M.D. Conflicts about water in Lake Chad: Are environmental, vulnerability and security issues linked? Prog. Dev. Stud. 2015, 15, 308-325. [CrossRef]

77. Lemoalle, J.; Bader, J.-C.; Leblanc, M.; Sedick, A. Recent changes in Lake Chad: Observations, simulations and management options (1973-2011). Glob. Planet. Chang. 2012, 80-81, 247-254. [CrossRef]

78. Likoya, E. Climate Change in the Context of Changing Land Use and Cover: Case Study of the Shire River Basin Flood of 2015 Master's Thesis, University of Cape Town, Cape Town, South Africa, 2019.

79. Limuwa, M.M.; Sitaula, B.K.; Njaya, F.; Storebakken, T. Evaluation of Small-Scale Fishers' Perceptions on Climate Change and Their Coping Strategies: Insights from Lake Malawi. Climate 2018, 6, 34. [CrossRef]

80. Desta, H.; Lemma, B.; Albert, G.; Stellmacher, T. Degradation of Lake Ziway, Ethiopia: A study of the environmental perceptions of school students. Lakes Reserv. Res. Manag. 2015, 20, 243-255. [CrossRef]

81. Cowx, I.G.; Aya, M.P. Paradigm shifts in fish conservation: Moving to the ecosystem services concept. J. Fish. Biol. 2011, 79, 1663-1680. [CrossRef]

82. Wood, A.; Dixon, A.; McCartney, M. Wetland Management and Sustainable Livelihoods in Africa; Routledge: London, UK; New York, NY, USA, 2013.

83. Williams, M.; Ryan, C.; Rees, R.; Sambane, E.; Fernando, J.; Grace, J. Carbon sequestration and biodiversity of re-growing miombo woodlands in Mozambique. For. Ecol. Manag. 2008, 254, 145-155. [CrossRef]

84. Nkwanda, I.S.; Feyisa, G.L.; Zewge, F.; Makwinja, R. Impact of land-use/land-cover dynamics on water quality in the Upper Lilongwe River basin, Malawi. Int. J. Energy Water Resour. 2021, 5, 193-204. [CrossRef]

85. Guo, H.; Hu, Q.; Jiang, T. Annual and seasonal streamflow responses to climate and land-cover changes in the Poyang Lake basin, China. J. Hydrol. 2008, 355, 106-122. [CrossRef]

86. Li, K.; Coe, M.; Ramankutty, N.; De Jong, R. Modeling the hydrological impact of land-use change in West Africa. J. Hydrol. 2007, 337, 258-268. [CrossRef]

87. Dasgupta, R.; Shaw, R. Cumulative Impacts of Human Interventions and Climate Change on Mangrove Ecosystems of South and Southeast Asia: An Overview. J. Ecosyst. 2013, 2013, 1-15. [CrossRef]

88. Hara, M. Restoring the chambo in Southern Malawi: Learning from the past or reinventing the wheel? Aquat. Ecosyst. Health 2016, 9, 419-432. [CrossRef]

89. Froese, R.; Walters, C.; Pauly, D.; Winker, H.; Weyl, O.L.F.; Demirel, N.; Tsikliras, A.C.; Holt, S.J. A critique of the balanced harvesting approach to fishing. ICES J. Mar. Sci. 2015, 73, 1640-1650. [CrossRef]

90. Tweddle, D.; Turner, G. Evidence for lacustrine breeding by sanjika Opsaridium microcephalum (Teleostei: Cyprinidae) in Lake Malawi. Afr. J. Aquat. Sci. 2014, 39, 479-480. [CrossRef]

91. Weyl, O.; Ribbink, A.J.; Tweddle, D. Lake Malawi: Fishes, fisheries, biodiversity, health and habitat. Aquat. Ecosyst. Health Manag. 2010, 13, 241-254. [CrossRef]

92. Mkumbo, O.C.; Marshall, B. The Nile perch fishery of Lake Victoria: Current status and management challenges. Fish. Manag. Ecol. 2015, 22, 56-63. [CrossRef]

93. Stauffer, J.R.; Madsen, H. A one health approach to reducing schistosomiasis transmission in Lake Malawi. Prev. Med. Community Health 2018, 1, 1-4. [CrossRef]

94. Khonje, A.; Metcalf, C.A.; Diggle, E.; Mlozowa, D.; Jere, C.; Akesson, A.; Corbet, T.; Chimanga, Z. Cholera outbreak in districts around Lake Chilwa, Malawi: Lessons learned. Malawi Med. J. 2012, 24, 29-33. [PubMed]

95. Derne, B.; Weinstein, P.; Lau, C.L. Wetlands as Sites of Exposure to Water-Borne Infectious Diseases. In Wetlands and Human Health. Wetlands: Ecology, Conservation, and Management; Springer: Dordrecht, The Netherlands, 2015; pp. 45-74. 
96. Pullanikkatil, D.; Palamuleni, L.; Ruhiiga, T. Assessment of land-use change in Likangala River catchment, Malawi: A remote sensing and DPSIR approach. Appl. Geogr. 2016, 71, 9-23. [CrossRef]

97. Gian-Reto, W. Community and ecosystem responses to recent climate change. Philos. Trans. R. Soc. B 2010, 365, 2019-2024. [CrossRef]

98. Etiegni, C.A.; Irvine, K.; Kooy, M. Participatory governance in Lake Victoria (Kenya) fisheries: Whose voices are heard? Marit. Stud. 2020, 19, 489-507. [CrossRef]

99. Abebe, G. Cash-for-work and food-for-work programs' role in household resilience to food insecurity in southern Ethiopia. Dev. Pract. 2020, 30, 1068-1081. [CrossRef]

100. Yu, H.; Yang, Z.; Li, B. Sustainability Assessment of Water Resources in Beijing. Water 2020, 12, 1999. [CrossRef]

101. Mann, T.; Gerwat, W.; Batzer, J.; Eggers, K.; Scherner, C.; Wenck, H.; Stäb, F.; Hearing, V.J.; Röhm, K.H.; Kolbe, L. Inhibition of human tyrosinase requires molecular motifs distinctively different from mushroom tyrosinase. J. Investig. Dermatol. 2018, 138, 1601-1608. [CrossRef] [PubMed]

102. Le Anh, H.; Schneider, P. A DPSIR Assessment on Ecosystem Services Challenges in the Mekong Delta, Vietnam: Coping with the Impacts of Sand Mining. Sustainability 2020, 12, 9323. [CrossRef]

103. Eneyew, B.G.; Assefa, W.W. Anthropogenic effect on wetland biodiversity in Lake Tana Region: A case of Infranz Wetland, Northwestern Ethiopia. Environ. Sustain. Indic. 2021, 12, 100158. [CrossRef]

104. Elias, E.; Seifu, W.; Tesfaye, B.; Girmay, W. Impact of land use/cover changes on lake ecosystem of Ethiopia central rift valley. Cogent Food Agric. 2019, 5, 1595876. [CrossRef] 